\title{
ANL-EP-TM-92/1
}

\author{
Argonne National Laboratory \\ 9700 S. Cass Avenue \\ Argonne, IL 60439
}

\section{CORE LENGTH TESTABLE REACTOR CONCEPT NEUTRONIC ANALYSIS}

N.A. Hanan and S.K. Bhattacharyya Engineering Physics Division

September 1992

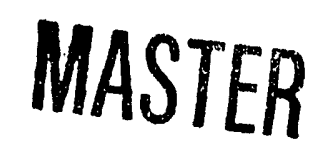


ABSTRACT .................................... vii

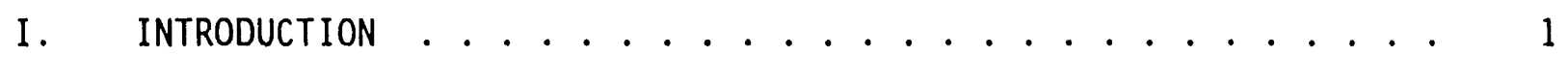

A. Background ................. 1

B. Proposed Statement of Work . . . . . . . . . . . . 1

C. Core Concepts Analyzed ............. 2

II. CALCULATIONAL METHOdOLOGY ................ 2

III. REACTOR MODELS ANALYZED AND RESULTS . . . . . . . . . . 5

A. $40 \mathrm{kWe}$ Concepts................. 5

1. Zirconium Hydride Moderated Core ......... 5

2. Rod Moderated Core: Be and ZrH as Moderators . . . 7

3. Yttrium Hydride-Beryllium Moderated Core . . . . 7

B. $10 \mathrm{kWe}$ Concept ................ . . 12

IV. SUMMARY AND RECOMMENDATIONS . . . . . . . . . . . . . . 12

REFERENCES .............................. 14 


\section{FIGURES}

1. Flowchart of Analytical Approach ............. 15

2. Temperature Effect of Reactivity of the TOPAZ Converter Reactor with Single-Element TFE .............. 16

3. Normalized Radial Power for the YH Core (Base Case) . . . . . . 17

4. Normalized Axial Power for the YH Core (Base Case) . . . . . . 18

5. Normalized TFE Power for the YH Core (Base Case . . . . . . . 19

6. Normalized Flux Spectra for the YH Core (Base Case) . . . . . 20

7. Normalized Flux Spectrum for the Moderator Region at Low Energy: YH Core (Base Case)................ 21

8. Normalized Power and Flux for One TFE: YH Core (Base Case) . . . 22

9. YH Core (Base Case): Control Drums (12) as a Function of Rotation Angle................... 23

10. YH Core (Base Case): Burnup Reactivity Loss with Operation Time 24

11. YH Core (Base Case): Normalized Radial Power at BOL and EOL (Control Drums Out) .............. 25

12. YH Core (Base Case): K-Effective for Different Configurations . 26 


\section{TABLES}

I. MCNP Cross Section Validation ............ 27

II. $40 \mathrm{kWe}$ Zirconium Hydride Core - TFE Cross Section . . . . . 27

III. $\quad 40 \mathrm{kWe}$ Design Analysis Summary . . . . . . . . . . . 28

IV. $\quad 40 \mathrm{kWe}$ Zirconium Hydride Core - Core Characteristics . . . 29

V. $\quad 40 \mathrm{kWe}$ Zirconium Hydride Core - Cross Section Validation . 29

VI. $\quad 40 \mathrm{kWe}$ Zirconium Hydride Core - Control Drums Worth .... 30

VII. $\quad 40 \mathrm{kWe}$ Zirconium Hydride Core - Moderator Temperature Coefficient .............. 30

VIII. $\quad 40 \mathrm{kWe}$ Zirconium Hydride Core - Temperature Reactivity Coefficients .............. 30

IX. $\quad 40$ kWe Zirconium Hydride Core - Neutron Kinetics Parameters 31

X. $\quad 40$ kWe Rod Moderated Core - TFE Cross Section ....... 31

X1. $\quad 40$ kWe Rod Moderated Core - Moderated Rod Cross Section . . 31

XII. $\quad 40$ kWe Rod Moderated Core - Core Characteristics ..... 32

XIII. $\quad 40 \mathrm{kWe}$ Rod Moderated Core - Control Drums Worth . . . . . 33

XIV. $\quad 40$ kWe Rod Moderated Core - Submersion Analysis . . . . . 33

XV. $\quad 40$ kWe Rod Moderated Core - Sensitivity Study . . . . . . . 33

XVI. $\quad 40 \mathrm{kWe}$ Rod Moderated Core Moderator/Reflector Temperature Reactivity Coefficients ........... 34

XVII. $\quad 40 \mathrm{kWe}$ Yttrium Hydride Core - Core Characteristics . . . 34

XVIII. $\quad 40 \mathrm{kWe}$ Yttrium Hydride Core - TFE Cross Section . . . . . 35

XIX. $\quad 40 \mathrm{kWe}$ Yttrium Hydride Core - Central Control Rod . . . . 35

XX. $\quad 40 \mathrm{kWe}$ Yttrium Hydride Core - Control Drums/Safety Rod Worth 35

XXI. $\quad 40 \mathrm{kWe}$ Yttrium Hydride Core - Cross Section Validation . . 36

$\begin{array}{ll}\text { XXII. } & 40 \mathrm{kWe} \text { Yttrium Hydride Core - Temperature Reactivity } \\ & \text { Coefficients . . . . . . . . . . } 36\end{array}$

$\begin{array}{ll}\text { XXIII. } & 40 \mathrm{kWe} \text { Yttrium Hydride Core - Summary of Reactivity } \\ & \text { Requirements . . . . . . . . . . . } 37\end{array}$ 


\section{TABLES (contd.)}

XXIV. $\quad 40 \mathrm{kWe}$ Yttrium Hydride Core - Sensitivity Study . . . . . 38

XXV. $\quad 40 \mathrm{kWe}$ Yttrium Hydride Core - Submersion Analysis . . . . 39

XXVI. $\quad 40$ kWe Yttrium Hydride Core - Neutron Kinetics Parameters . 39

XXVII. $\quad 40 \mathrm{kWe}$ Yttrium Hydride Core - Hydrogen Loss . . . . . . . 40

$\begin{array}{ll}\text { XXVIII. } & 40 \mathrm{kWe} \text { Yttrium Hydride Core - Modification 1 - Control } \\ & \text { Drums/Safety Rod Worth . . . . . . . . . . } 40\end{array}$

XXIX. $\quad 40 \mathrm{kWe}$ Yttrium Hydride Core - Modification 1 - Submersion Analysis ................ 4 40

XXX. $\quad 40 \mathrm{kWe}$ Yttrium Hydride Core - Modification 2 ....... 41

XXXI. $\quad 40$ kWe Yttrium Hydride Core - Modification 2 ...... 42

XXXII. $\quad 10$ kWe Yttrium Hydride Core - Core Characteristics . . . . 42

XXXIII. $\quad 10$ kWe Yttrium Hydride Core - TFE Cross Section ...... 43

XXXIV. $\quad 10 \mathrm{kWe}$ Yttrium Hydride Core - Driver Cross Section . . . 43

XXXV. $\quad 10 \mathrm{kWe}$ Yttrium Hydride Core - Control Drums/Safety Rod Worths ................. 43

XXXVI. $\quad 10$ kWe Yttrium Hydride Core - Temperature Reactivity Coefficients ............... 44

XXXVII. $\quad 10$ kWe Yttrium Hydride Core - Submersion Analysis . . . . 44 
CORE LENGTH TESTABLE REACTOR CONCEPT NEUTRONIC ANALYSIS

by

N. A. Hanan and S. K. Bhattacharyya

ABSTRACT

Development work on thermionic reactor systems has been ongoing in the U.S. since the early 1950s. While significant successes were achieved, progress has been hampered by frequent changes in direction and funding instabilities (as has been true for many high tect.iology initiatives). The recent Air Force thernionics initiative (1991) represents the latest in the: mionics reactor development in the U.S. This Air Force initiative called for the development of thermionics reactors with the output power of about 40 kWe, and which incorporated the features of testability, fabricability, low development cost, high level of safety and reliability, and survivability.

The Russian thermionics program has had a more stable development over the past 30 plus years and has produced two recent flight tested TOPAZ reactor units in addition to a large number of ground test units. In view of the rapidly improving relations between the U.S. and FSR, it was logical to look at the extensions of TOPAZ technology to meet the Air Force requirements. The strong ties between Space Power, Inc. (SPI) and the key Soviet institutions made it possible for SPI to propose such a concept to the Air Force. Argonne National Laboratory served as a subcontractor to SPI in this effort, supporting the prime contractor in the areas of core design and safety analysis.

Several concepts were analyzed to define a design that would meet all the requirements set forth by the Air Force. This report describes the methodology used, the different designs analyzed and reasons for the evolution of the design, and presents the results for the different concepts. 
I. INTRODUCTION

\section{A. Background}

Development work on thermionic reactor systems has been ongoing in the US since the early 1950s. Progress has been hampered by frequent changes in direction and funding instabilities. The SP-100 power system selection provided the latest opportunity for thermionics space power systems to be considered (in the early 1980s). The decision was made to go with thermoelectric partially because of the perceived advantage in maturity of thermoelectric technology over thermionic technology. A thermionic fuel element (TFE) verification program was initiated in 1980 and is presently in progress, developing the test data for TFEs designed for MW class thermionic systems. The recent Air Force thermionics initiative, for which the present work was performed, represents the latest in thermionics reactor development in the US.

In contrast, thermionics has enjoyed steady support in the Former Soviet Union (FSR) starting from about 1958 when the technology was first introduced to them from the US. The steady development has culminated in the production and testing of a number of thermionics reactors including the space flight tests of multicell thermionic TOPAZ reactor systems in 1987 and 1988 . A recent development includes single cell TOPAZ-II reactors that offer the advantage of electrically heated testability. As a general statement, it is fair to say that the thermionics data base in the FSR represents thousands of man years of effort.

The Air Force thermionics initiative called for the development of thermionics reactors with the output power of about $40 \mathrm{KWe}$, and which incorporated the features of testability, fabricability, low development cost, high level of safety and reliability, and survivability. In view of the rapidly improving relations between the US and FSR, it was logical to look at the extensions of TOPAZ technology to meet the Air Force requirements. The strong ties formed between Space Power, Inc. (SPI) and the key Soviet institutions made it possible for SPI to propose such a concept to the Air Force. Argonne National Laboratory served as a subcontractor to SPI in this effort, supporting the prime contractor in the areas of core design and safety analysis. This report presents results of the work done.

\section{B. Proposed Statement of Work}

The statement of work was designed to assist Space Power Inc. (SPI) in the neutronic analysis of their Core Length Testable Reactor Concept. The scope of the work to be performed follows:

1. Assistance in the neutronic design of three reactor cores (40 kWe, $100 \mathrm{kWe}$ and $10 \mathrm{kWe}$ ); detailed neutronic analysis for the $40 \mathrm{kWe}$ core and briei analysis for the other two cores. In this area ANL would perform analyses to: a) determine reactivity loss due to burnup of actinides and buildup of fission products over the 10 year life of the reactor; b) confirm safety margins for the designs under postulated accident conditions for the reference design (the postulated configurations would be provided by SPI); c) determine reactivity effect due to moderator temperature coefficient and to determine the Doppler reactivity effect of the fuel and emitter. 
validation.

2. Assistance in specifying a development plan for technology

3. Participation in two meetings and presentations.

This report addresses only item 1 above, i.e., the neutronic design analysis.

\section{Core Concepts Analyzed}

Since the main objective of the work was to define a design that would meet all the requirements (not only neutronics) for the $40 \mathrm{kWe}$ system, several concepts were analyzed for this power level. A short description of the concepts analyzed follows, and the results and reasons for going to different designs are presented in section III of this report. The starting point was a design similar to the Soviet TOPAZ reactor, a Zirconium Hydride ( $\mathrm{ZrH})$ moderated system in which the TFEs are placed in a matrix of $\mathrm{ZrH}$; even though this core did not meet the requirements all the analysis described in item a) of section I.1 were performed for this core because some qualitative comparisons could be made with results published for the TOPAZ reactor, and this would help in the validation of the methods used in the analysis. Next a concept in which rows of TFE and Be-ZrH rods are alternated in the core was analyzed. Following this concept, a Beryllium-Yttrium Hydride moderated core was analyzed, and since with some modifications this design would be able to meet the requirements, a more complete analysis was then performed for this core. Late in this project some of the modifications to this Be-YH core were implemented and a partial analysis of this latest design was performed.

For the $10 \mathrm{kWe}$ design an abbreviated analysis was performed for one concept which also uses Be-YH as moderator; in this concept drivers are also used in the core.

As for the $100 \mathrm{kWe}$ design a decision was made by SPI to not perform any analysis for this power level. This did not represent a reduction in workscope since the effort on the $40 \mathrm{kWe}$ system more than compensated for it.

The methods used in all these analyses are presented in Section II, and a description of the reactors analyzed together with the results of the analyses are presented in Section III. In Section I' a summary with recommendations for the definition of a final design is presented.

\section{CALCULATIONAL METHODOLOGY}

The analysis and design data presented below are based on current methods and state-of-the-art codes in the field of reactor physics. A flowchart of the design analysis steps used in the present study is presented in Figure 1 , and a short description of the computer codes used in the different steps of the analysis follows.

For general neutronic static analysis the Monte Carlo code MCNP(1) was always used; MCNP was also the code used for control evaluation and safety analysis (submersion). MCNP solves the Boltzmann transport equation for complex geometries using the Monte Carlo method; MCNP has options for continuous and multigroup energy cross section treatment and here the 
continuous energy treatment was always used. DIF3D, ${ }^{(2)}$ which solves the neutron diffusion equation in one, two or three dimensions, and TWODANT, (3) which provides a discrete ordinate multigroup solution for the Boltzmann transport equation in one or two dimensions and includes treatment of anisotropic scattering effects were also used to benchmark against MCNP for other calculations; note that only the one-dimensional option of TWODANT was exercised in the results presented in this report.

For depletion analysis, REBUS $-3^{(4)}$ which is a code designed for analysis of fuel cycle was used. REBUS-3 solves the non-equilibrium operation of the reactor under the specified set of operating conditions governing power levels and operating time. For the solution of the depletion problem in REBUS-3, the total reactor burn cycle is divided in several subintervals (defined by the user), and a explicit burnup is performed in each region of the reactor over each of these subintervals using the average reaction rates over the subinterval; these average reaction rates are based on fluxes obtained from the diffusion theory solution at both the beginning and end of the subinterval. The transmutation equations are solved by the matrix-exponential technique and the isotopes to be considered in the burnup equations, as well as their transmutation reactions, are specified by the user. Following agreement with SPI, two-dimensional (RZ) models of the reactors analyzed were used in the depletion analyses. Note that REBUS-3 is also the code of choice in the definition of enrichment zones (or moderator-to-fuel ratios) with the objective of flattening the power distribution throughout the cors, even though this capability was not used in this phase of the design analysis.

For the determination of kinetics parameters several codes were used. The effects of the moderator temperature were analyzed with MCNP and using a detailed core model. The determination of the Doppler reactivity effects for the fuel and emitter was performed using a unit-cell concept with the onedimensional option of the TWODANT transport code; this choice for this phase of the design was a decision made in agreement with SPI due mainly to level of effort constraints. For the determination of the neutron generation time, delayed neutron fractions and decay constants the code VARI-3D, ${ }^{(5)}$ a diffusion theory perturbation theory code, was used. It is important to note that neutronics effects of the photoneutrons (delayed neutrons) emitted as a result of photnn $(r, n)$ interaction were not included in the determination of neutron generation time and delayed neutron fractions; for slow transients, power shaping and effect of control drums motions, the delayed effect of photoneutrons could be significant.

Because the validity of calculations depends strongly on the accuracy of the cross sections on which the calculations are based, special care must be taken in the generation of accurate multigroup cross sections. The following were the methods used in the generation and use of the cross sections:

1. MCNP analysis: For the calculations performed with MCNP, the cross sections used were those obtained from Los Alamos and included with the MCNP code package. These cross sections were basically room temperature cross sections for all isotopes in the different cores and higher temperature cross sections for the $\mathrm{ZrH}$ and Be; for these high temperatures, the MCNP cross sections also includes the thermal neutron scattering kernels [S( $\alpha, \beta)$ treatment]. It is important to note that MCNP does not have the $S(\alpha, \beta)$ treatment for the Yttrium Hydride moderator and the $S(\alpha, \beta)$ for the $H$ in $\mathrm{ZrH}$ was 
then used (the decision to use this as a surrogate for YH was made in agreement with SPI).

Even though the cross sections in MCNP have been widely used by several other groups, and are supposed to be well tested, validation of some of these cross sections was performed in two ways. First, calculations for several criticals using a sphere of highly enriched uranium surrounded by Be reflector were performed and the results are presented in Table I. Also, using a homogeneous model for the SNAP Experimental Reactor (SER) as given in NAA-SR$5619^{(6)}$ an MCNP calculation was performed with the critical configuration (55.2 fuel elements) and the result is also presented in Table $I$.

The results in Table I basically validate the MCNP cross sections (for the materials present in those calculations).

2. Depletion Analysis: Because of funding limitation and the extensive time needed for the generation of fission products cross sections, a decision was made (in agreement with SPI) to use the EPRI-CELL (7) code for the generation of cross sections for burnup analysis; 97-group EPRI-CELL cross sections for most of the isotopes in the cores to be analyzed were already available at ANL and this would be adequate for this phase of the design. The EPRI-CELL code utilizes a 62-group fast GAM library and a 35-group s10w THERMOS library. The cross section library for EPRI-CELL has been processed by the MC2-2(8) code for the fast library and by the NJOY(9) code for the thermal library; thermal neutron scattering kernels derived from ENDF/B-V data for $H$ bound in $\mathrm{ZrH}$ are present in the ANL EPRI-CELL library. This same process was used to generate cross sections for the materials in the thermionic cores not present in the existing ANL EPRI-CELL library ( $Y$, and $W$ isotopes).

EPRI-CELL is a one-dimensional (cylinder or slab) transport code which determines the neutron spectrum as a function of space, energy and time; for this work, burnup-dependent cross sections were not generated, i.e. cross sections at BOL were used in the burnup calculations. Broad-group crosssections result from collapsing the GAM/THERMOS fine group cross sections over that spectrum. In this work a 15-group structure ( 9 fast and 6 slow neutron groups) was generated from EPRI-CELL and then used in the REBUS-3 depletion analyses, and in the VARI-30 calculations. Note that 15-group cross sections were generated for each of the cores analyzed in this work.

The cross sections generated from EPRI-CELL were then validated (for each of the cores analyzed) by comparing the results with those obtained with MCNP; these results are presented in Section III for each of the concepts analyzed, and the agreement with MCNP is very good.

3. Doppler Effect Calculations: For the analys is of the Doppler effect the NJOY code was used to provide a 97-group cross section set for use in the TWODANT transport code; P3 cross sections were generated. One set of NJOY cross sections was generated for room temperature and cross sections at $1000 \mathrm{~K}$ were generated for the fuel and emitter/collector materiais. This set of cross sections was generated at the beginning of this work and the compositions used for the calculation of the potential cross sections (these are used in the calculation of the self-shielded pointwise cross sections) were those present in the concept defined at that time and shown in Tabie II. Due to level of effort constraints in this phase of the design, these cross 
sections were used for Doppler effect calculations for all the concepts analyzed.

The room temperature cross sections generated by using NJOY were then used in unit cell calculations to compare against MCNP unit cell calculations. The results of these comparisons are presented in Section III for each of the concepts analyzed, and they were considered adequate for this phase of the design.

\section{REACTOR MODELS ANALYZED AND RESULTS}

\section{A. $40 \mathrm{kWe}$ Concepts}

Several concepts were analyzed for this power level. A summary of the concepts analyzed and the reason(s) for going to a different concept is presented in Table III. The specific results obtained for each concept are discussed below.

\section{Zirconium Hydride Moderated Core}

This concept is similar to the TOPAZ reactor. A $52 \mathrm{~cm}$ core containing 151 TFEs with an active length equal to $35 \mathrm{~cm}$, surrounded by a 10 $\mathrm{cm} \mathrm{Be}$ radial reflector and 12 control drums are the major components of this core. Tables II and IV give the characteristics of the Thermionic Fuel Elements and the core, respectively. The major differences between this core and TOPAZ (based on published information) are the core size (about $30 \mathrm{~cm}$ for TOPAZ) and the emitter thickness ( $1 \mathrm{~mm}$ thickness in TOPAZ vs $2 \mathrm{~mm}$ in this design).

Multigroup cross sections (15 and 97 groups) were generated for this core and comparisons with MCNP analysis are presented in Table V; differences of less than $2 \%$ were obtained, and due to 1 imitations in level of effort the cross sections were considered adequate for this phase of the design.

A burnup calculation was performed (REBUS-3 code) using an RZ model and the 15-group cross section set and a 3.45 percent burnup swing reactivity was calculated for a ten-year operation at a thermal power level equal to $629 \mathrm{~kW}(\mathrm{th})$. Next the MCNP code was used to determine the worth of the control drums, since one of the requirements of this design is that the control drums must have enough reactivity to control the reactor. The results of these MCNP calculations, provided in Table VI, indicated a very small worth for the control drums (about 2.2 percent); this small worth is due to the large diameter of the core. Based upon these results it was clear that this concept would not meet the requirements, and it was not considered further.

Since this concept was similar to TOPAZ and there is some information available on several neutronic characteristics of this core, determination of several parameters was performed to confirm (at least qualitatively) some of the results presented in the FSR-published results.

The most unique characteristic of the TOPAZ reactor is its positive moderator temperature reactivity coefficient. A physical explanation for this effect can be described as follows. The temperature effect arises from the temperature dependence of the thermal scattering for the $\mathrm{ZrH}$. The high 
temperature hardens the neutron spectrum and as a consequence the absorpticns and fissions decrease (reduced cross sections at the higher neutron energies). The decrease in the absorptions is larger than the decrease in the fissions since the fuel is quite black at these neutron energies. The FSR-published results and another study ${ }^{(10)}$ have shown that this temperature effect decreases with the temperature as shown in Figure 2. The MCNP analys is performed for the $40 \mathrm{kWe} \mathrm{ZrH}$ moderated core basically confirms the trends shown in the FSRpublished results up to a temperature of $800 \mathrm{~K}$; these results are shown in Table VII and plotted in Figure 2. However for the next higher temperature available in MCNP cross sections, i.e. $1200 \mathrm{~K}$, there is a large increase in the temperature effect. Since there is no explanation for this quite larae increase, the only possible factor is the validity of the $1200 \mathrm{~K}$ cruss sections. It is important to note that LANL analysts have also uncovered the same problem with the $\mathrm{ZrH}$ high temperature $(1200 \mathrm{~K})$ cross sections in the analysis for their reactor design, as discussed in their August 26 presentation to the Air Force. Note also that the absolute values calculated for this concept (up to $800 \mathrm{~K}$ ) are much smaller than those for TOPAZ; most of this difference can probabiy be attributed to the different thickness of the Mo in the emitter in the TFE ( $1 \mathrm{~mm}$ in TOPAZ vs $2 \mathrm{~mm}$ in this analyzed concept), however no effort was made to explain this difference because of lack of detailed information on the TOPAZ reactor.

An analysis was also performed to compare the moderator temperature effect as calculated with MCNP with that calculated with cross sections generated with NJOY; a 97-group cross section for $\mathrm{ZrH}$ at $1200 \mathrm{~K}$ was generated with NJOY (methodology described above in item c) of Section II) and a unit cell calculation was performed with TWODANT. This comparison shows that there is only a $10 \%$ difference between MNCP and NJOY-TWODANT unit cell (MCNP is larger); since MCNP also uses NJOY for the process of cross section generation, it seems that the problem with the $1200 \mathrm{~K} \mathrm{ZrH}$ cross section (if any problem does exist) might come from the ENDF/B-V thermal scattering (note that this is speculation, and the effort to try to figure out the reasons for this difference is beyond the scope of this work).

Calculations were also performed to qual itatively compare the Doppler reactivity effects for the fucl and the emitter. The results of these calculations for this $\mathrm{Zr}-\mathrm{H}$ moderated concept are presented in Table VIII, and the single points calculated for the emitter and fuel are al so shown in Figure 2 where it can be seen that as in TOPAZ these effects are negative and small. Again, in figure 2 it can be seen that the emitter Doppler effect is larger (absolute value) in this design, when compared to TOPAZ, and this is probably due to the emitter thickness difference.

One the drawbacks of the TOPAZ design is the large decrease in k-effective due to loss of hydrogen over life (diffusion at elevated temperatures). A calculation was performed for this $\mathrm{Zr}-\mathrm{H}$ moderated design and for a $10 \%$ (weight percent) loss of hydrogen there is a $1.4 \%$ decrease in $k-$ effective.

Finally, the neutron generation time, the delayed neutron fractions and decay constants were also calculated for this concept and the results are given in Table IX. It is important to note that as stated in Section II above the effect of photoneutrons from the Be reflector were not taken into account in the results presented above; a delayed neutron fraction 
equal to 0.0072 was calculated. As a point of comparison, the delayed neutron fraction extracted from measurements in the SNAP Experimental Reactor (NAA-SR5619), was equal to 0.0085 with an accuracy no better than 5 to $10 \%$.

\section{Rod Moderated Core: Be and ZrH as Moderators}

The main problem with the $\mathrm{ZrH}$ moderated core was the lack of available control with control drums, which is mainly due to the large diameter of the core. The other negative characteristic of the $\mathrm{ZrH}$ moderated core is the large loss of reactivity with loss of hydrogen. The way to try to decrease these two problems was to design a core in which the moderator would be made out of $\mathrm{ZrH}$ rods enclosed in Cery?lium. This would decrease the hydrogen loss and also make possible a smaller core; studies performed by Los Alamos have indicated that certain ratios of $\mathrm{Be}$ and $\mathrm{ZrH}$ would permit a smaller core than either moderator by itself.

This Be-ZrH rod moderated core containing 151 TFEs and 120 moderator rods, and a core with an equivalent diameter equal to $44.2 \mathrm{~cm}$ was proposed. Tables X, XI and XII present the characteristics for the TFE, Moderator Rod and Core, respectively. For this core, the first analysis performed was a burnup analysis, and the results indicated a $3.83 \%$ burnup swing reactivity. Next, the calculation of the worth of the control drums was performed, and as shown in Table XIII, a worth of $6.74 \%$ (delta $k$ ) was determined; this indicated, in principle, the feasibility of this concept. Then, safety analyses were performed with MCNP to determine the subcriticality of the reactor given a water submersion accident. The results of this analysis are presented in Table XIV, and it was determined that there would be problems with submersion. A first possibility to solve this problem would be to replace the central TFE with a safety rod (with Be follower) that would be withdrawn for reactor startup. Even with the inclusion of this safety rod the reactor would still not meet the criteria for submersion, as seen in Table XIV. Since this concept also had a lack of excess reactivity, sensitivity studies were performed to verify possible means of increasing the beginning of life reactivity; this analys is showed that an increase of about $2.7 \%$ in k-effective could be obtained by increasing enrichment and the size of the radial reflector (see Table XV). Finally, calculations were also performed to determine the moderator and radial reflector temperature coefficients; these results, presented in Table XVI, showed a positive moderator feedback (smaller than for the $\mathrm{ZrH}$ moderated concept) and apparently a very small positive radial reflector temperature reactivity coefficient (the uncertainty in the calculation was still too high when compared with the difference in $k$ ).

There were possible means to modify this design to meet the requirements. However, SPI tests/analysis indicated that even with the Beenclosed $\mathrm{ZrH}$, there would still be problems of loss of hydrogen to make the design uncertain, and a decision was made to discard this design.

\section{Yttrium Hydride-Beryllium Moderated Core}

Since the containment of hydrogen was still a problem even with the Be enclosed $\mathrm{ZrH}$, SPI decided to substitute the $\mathrm{Zr}$ by Yttrium in the hydride. This substitution "potentially offers a high reliability, and a lower cost solution to the problem of hydrogen containment for the long life of the core; this is due to the fact that the $\mathrm{YH} \cdot$ dissociation pressure is 2 to 3 
orders of magnitude lower than that of the $\mathrm{ZrH}$ at the operating temperature." In this concept the YH is also enclosed by Beryllium.

Three versions of this Be-YH moderated core were analyzed; the base case for which detailed analysis was performed, and two modifications to the base case for which, due to the lateness of the information and due to level of effort constraints, only partial analyses were performed.

\section{a. Be-YH Moderated Core: Base Case}

The characteristics of this core, of the TFE and of the central safety rod are presented in Tables XVII, XVIII and XIX, respectively. This core contains 150 TFEs in a hexagonal pitch equal to $3.4125 \mathrm{~cm}$; the equivalent core diameter is $45.4 \mathrm{~cm}$ and the core active length is equal to 35 $\mathrm{cm}$. Radially the core is enclosed in a $2 \mathrm{~mm}$ stainless steel vessel. Surrounding the vessel is the $10 \mathrm{~cm}$ Be radial reflector inside which there are 12 control drums containing $\mathrm{Be}$ and $\mathrm{B}_{4} \mathrm{C}$. Each drum consists of a $10.4 \mathrm{~cm}$ diameter solid block of $\mathrm{Be}$ with a $1 \mathrm{~cm}$ lens of enriched $\mathrm{B}_{4} \mathrm{C}$ along its outer boundary. A ten centimeter axial reflector is placed in each end of the fuel, and at the time of this design the axial reflector geometry had not been completely defined and a homogeneous mixture of Mo, Be, SS316L and NaK was used.

First an MCNP analysis was performed to determine the control drums and safety rod worth for this core; the results of this analysis shown in Table $X X$, indicated that the drums, with a worth equal to $7.7 \%$ (delta $k$ ), would probably be able to meet the control requirements of this core (based on the previous concepts analyses).

Figures 3 and 4 present the normalized radial power at the core centerline and the normalized axial power at the TFE closest to the center of the core, respectively; in both cases the power profile is for the case with the control drums in the least reactive position, i.e. control drums out. From Figure 3 it can be clearly seen that there is a need for power flattening, however a decision was made not to work on power flattening in this phase of the design. Figure 5 where the normalized power in each TFE with the "control drums out" and the "control drums in" positions are presented, shows even clearer the need for power flattening.

Figure 6 shows the spectra in the fuel and $\mathrm{YH}$ moderators (from MCNP calculations). The peak at $0.1 \mathrm{eV}$ region that has been reported in the work of other groups is clearly seen here in Figure 7 where the $\mathrm{YH}$ moderator spectrum is provided for only a small region of the spectrum. Since the spectra plot do not add much information about the characteristics of the reactor a plot of the normalized power and normalized flux in the fuel region is presented in Figure 8 . In this figure, it can be clearly seen that about $40 \%$ of the fissions in this core occur in the energy above $1 \mathrm{keV}$, and other $40 \%$ occur between $1 \mathrm{eV}$ and $1 \mathrm{keV}$. This shows that this concept is not a thermal reactor, but it is an intermediate spectrum reactor.

Figure 9 shows the worth of control drums as function of position of the poison section. The shape follows the S-curve form.

For the depletion analysis, EPRI-CELL cross sections were generated. As discussed before in the methodology section, the cross 
section validation against MCNP was then performed and the results shown in Table XXI indicate an adequate agreement; note that in Table XXI the transport analysis used in the comparison with MCNP was performed with the 97-group cross section generated for the $\mathrm{ZrH}$ moderated core. The depletion analysis was performed with REBUS-3 and a burnup swing reactivity equal to $3.62 \%$ was calculated. The burnup reactivity loss as a function of operation time is shown in Figure 10 where a basically linear relationship is seen. The radial power profiles at the beginning and end of life (based on calculations with the control drums out) are shown in Figure 11, where it can be seen that there is almost no shift in power due specifically to burnup; it is clear that there will be shifts in power when the movement of the control drums is simulated in the burnup analysis, a complexity which was not modeled in this phase of the design.

Next, the temperature reactivity coefficients for the moderator, reflector, fuel and emitter were calculated using the methodologies described in section II. The results of these calculations are presented in Table XXII where it can be seen that the fuel and emitter Doppler effects are small and negative and not much different from those calculated for the $\mathrm{ZrH}$ moderated core (see Tabie VIII). However, even though the moderator temperature coefficient is still positive its magnitude is much smaller than that for the $\mathrm{ZrH}$ moderated core.

Using the results presented so far, a partial table for the excess reactivity requirements was constructed and is given in Tabie XXIII. It is seen from this tatie that the beginning of life core must have an excess reactivity greater than $7 \%$ (deita $k$ ). Based on the worth of the control drums (about $7.7 \%$ ) it is seen that the controllability of this core with control drums only is marginal at be;t. Also, note that the core as proposed has a keffective equal to 1.014 , and means to increase the BOL excess reactivity were then investigated. Table XXIV shows some of the possible ways to increase the $\mathrm{BOL}$ reactivity; it is seen in that table that by increasing the fuel enrichment, by better design of the axial reflector and by increasing the thickness of the radial reflector it is possible to make this core meet the BOL excess reactivity requirements.

Since this concept showed possibility of meeting the requirements, the next step was the safety analysis, i.e analysis of the water submersion accident, for which the results are presented in Table XXV; a plot for k-effective for the control drums and safety rod in different combinations for the operational case and for the submersion case is presented in Figure 11. From this figure and Table $X X V$, and keeping in mind that the $B O L$ excess reactivity would have to be increased by at least $6 \%$, it is clearly seen that this concept, without modifications, would not meet the submersion subcriticality requirement.

Finally, since a very detailed analysis had already been performed for this concept the determination of the neutron kinetics parameters and the reactivity loss due to possible hydrogen losses were also performed and the results are presented in Tables XXVI and XXVII, respectively. Note that, as in the case for the $\mathrm{ZrH}$ moderated core, the effects of photoneutrons from Be were not accounted for in the calculation of the neutron kinetics parameters presented in Table XXVI. 


\section{b. Be-YH Moderated Core: Modification 1}

the only modifications were:

This core is basically the same as the base case and

- increased Fuel Smear Density from 60 to 73 percent, and

- the homogeneous axial reflector used in the base case was replaced by a detailed model of the axial reflector.

Both of these modifications, proposed by SPI, would basically increase the beginning of life reactivity of the core. MCNP calculations were performed to determine the BOL k-effective and the worth of the control drums, and the results are presented in Table XXVIII. From this table, it can be seen that there was an appreciable increase in k-effective (from 1.014 in the base case to 1.056), but there was also a decrease in the worth of the control diums (probably due to shift in importance from the TFEs in the outer rings to those in the inner rings). The excess reactivity requirements presented in Table XXIII indicates that even with those modifications there would not be enough excess reactivity at $\mathrm{BOL}$. A second problem with this modified core was that the control drums did not have enough worth for reactor control.

Since the detailed design of the axial reflector included a void region, a calculation in which Be replaces the void region in the axial reflector was performed and the results indicated a gain of about 2.5\%; this means that this core would have enough reactivity at BOL.

However, the other problem with the base case core was related to water submersion, and, as expected, the results of the water submersion case for this modified core, shown in Table XXIX, clearly show that the base core with these modifications would not meet the submersion safety requirements.

\section{c. Be-YH Moderated Core: Modification 2}

The changes made to this core were basically directed at addressing the two problems with the design: water submersion subcriticality and controllability with the control drums. The following were the modifications:

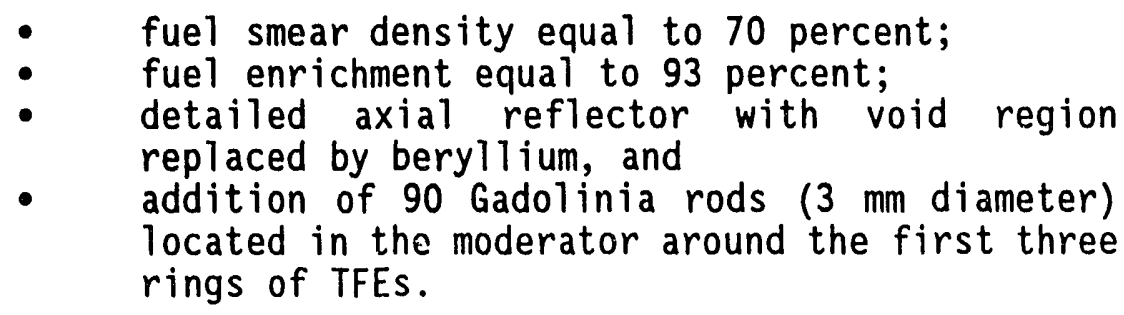

Clearly the first three modifications would add to the BOL k-effective, and the fourth modification would address the problem of controllability with the control drums. The fourth modification would also help in the water submersion problem. However, in order to be more effective 
for the water submersion case, the gadolinia rods should be located in the outer rings of TFEs; this is because in the submersion case, the drums and radial reflector are considered to be lost, and in that case the use of gadolinia in the outer rings would be more effective in absorbing the neutrons reentering the core after thermalization in the surrounding water.

These modifications to the base case were received in the beginning of August and as such only the SPI requested calculations were performed. Calculations were requested for this modified core with and without gadolinia, and the results are described below.

\section{No Gadolinia}

The results are presented in Table $X X X$, where it can be seen that even though the excess reactivity meets the requirements, the reactor cannot be controlled with the control drums alone. Also, the water submersion case confirms that these modifications alone do not solve the water submersion problem.

Calculations were also performed, as requested by SPI, for two possible cases of fuel redistribution (shapes defined by SPI), and they are also presented in Table XXX. In both cases there is not much change in reactivity (only about $\pm 0.4 \%$ ); even though no information was provided about these fuel redistribution cases, they seem to apply for normal operation and not for safety related purposes (speculation).

Finally, two calculations, for which the results are also presented in Table $X X X$, were performed to determine the reactivity effects due to:

(a) Radial and axial expansion (again dimensions provided by SPI): even with a very large number of histories in MCNP, the delta $k$ obtained (very small and negative) is smaller than the uncertainties in the calculation.

(b) Density change for NaK (from room temperature to $800 \mathrm{~K}$ ): again here the delta $k$ obtained (very small and negative) was smaller than the uncertainties in the calculation.

\section{With Gadolinia}

The addition of gadolinia has the objectives of providing enough control with the control drums and providing enough subcriticality for the water submersion accident. The results presented in Table XXXI show that there is enough control worth in the control drums, however the reactor is still basically critical when submerged in water.

It is worth to note that this concept with gadolinia can be modified to meet all the operational and safety requirements, however to do this an iterative process will be required. Due to level of effort and time constraints this iterative process was not performed at this phase of the design. 


\section{B. $10 \mathrm{kWe}$ Concept}

As described in the Introduction, only a partial analysis was performed for one core design at this power level. This reactor contains six driver fuel elements and 48 thermionic fuel elements in a hexagonal pitch equal to $4.5 \mathrm{~cm}$; the central element is a safety rod, and the drivers are located in the first row of fuel elements. The equivalent core diameter is $36.4 \mathrm{~cm}$. The core active length is $35 \mathrm{~cm}$, and the axial and radial reflector are the same as for the $40 \mathrm{kWe}$ defined in Section III.A.3.C above. As in the 1 ast $40 \mathrm{kWe}$ described above this core use $\mathrm{Be}$ and $\mathrm{YH}$ as the moderators. The characteristics of the core, TFE and driver fuel elements are presented in Tables XXXII, XYXIII and XXXIV respectively.

A depletion analysis using REBUS and the cross sections generated for the $40 \mathrm{kWe} B \mathrm{~B}-\mathrm{YH}$ moderated core was performed and a burnup swing equal to $2.5 \%$ was determined. The worth of the control drums was calculated and is presented in Table XXXV; it can be seen that controllability with the control drums wiil not be a problem for this concept.

Table XXXVI presents the results for the calculation of the temperature reactivity feedbacks for the moderator (MCNP analysis) and for the Doppler effects (based on a unit cell for the $d r$ a $r$ and for the TFE). As seen in that table, the Doppler effects are all negative and not much different from those calculated for the $40 \mathrm{kWe} B e-\mathrm{YH}$ design. However, the moderator feedback is positive and large as was the case for the $\mathrm{ZrH}$ core; note that the ratio of $H$ to $U$ in this core is much higher than that for the $40 \mathrm{kWe}$, and the driver elements are not enclosed in the MO-W emitter as is the case for the TFEs.

Finally, a water submersion analysis was performed and the results are presented in Table XXXVII, where it can be seen that this core will not have any problems in meeting the water submersion safety requirement.

In summary, it seems that this core can easily meet all the neutronic and water submersion safety requirements, but a complete analysis was not performed due to level of effort constraints.

\section{SUMMARY AND RECOMMENDATIONS}

Analyses were performed for the design of thermionic cores at two different power levels (40 kWe and $10 \mathrm{kWe}$ ) and the methodology used and results obtained were presented in detail.

For the $10 \mathrm{kWe}$ core, only a reduced analysis was performed, following the requirements of the statement of the work. This reduced analysis shows the feasibility of the proposed concept.

For the $40 \mathrm{kWe}$ reactor core several concepts were analyzed in detail to provide a final concept that would meet all the design requirements.

The first concept analyzed was a design similar to Russian TOPAZ design, which uses zirconium-hydride as moderator. Even though this concept did not meet the requirements, a detailed analysis was performed to provide some comparison with data published in the literature. Most of the published data was qualitatively confirmed, and the analysis uncovered a possible problem with 
the high temperature $(1200 \mathrm{~K})$ cross sections for the $\mathrm{ZrH}$; this problem was later confirmed by analysis performed by LANL for a different design.

The next $40 \mathrm{kWe}$ concept design analyzed used $\mathrm{ZrH}$ enclosed in Be to decrease the hydrogen loss (diffusion at the high operation temperature); this concept could meet the neutronic requirements, with some modifications, but loss of hydrogen would still be a problem. Thus, Yttrium was used to replace $\mathrm{Zr}$ in the next design analyzed; this substitution would provide the solution for the loss of hydrogen problem. Different designs using Be-YH as moderator were analyzed. Due to time/level of effort constraints, the analysis for the final concept for this phase of the project was not performed in detail. However, due to the similarities between the final concept (Be-YH Moderated Core: Configuration 2, described in section III.A.3 above), and the Base Case concept for the Be-YH moderated core it is recommended that the parameters evaluated for the base core be used to construct the characteristics of the final core for this phase of the design; obviously, the parameters will not be the same for both concepts, but the differences should not be large enough to make their use invalid. It is clear that in the next phase of the design, detailed analysis must be performed for what is defined as the "final" core in this report.

The analyses performed during this work have clearly shown that:

- There is a need for both deterministic and Monte Carlo design methods for the preparation of a defensible design.

- Generation of consistent cross sections for the specific designs is very important. For final designs, specific neutron crosssections must be generated.

- The most appropriate methods for the generation of the temperature effects are dependent upon the magnitude of the parameters being evaluated. For the generation of the moderator temperature effects, the use of MONTE CARLO codes is feasible for designs in which this parameter has a large magnitude; if the reactivity change effect is small, the uncertainties in the Monte Carlo calculations can be larger than the effect itself even if a very large number of histories is used. For the determination of the Doppler reactivity effect, it seems that the use of deterministic codes is a must because of the magnitude of the reactivity changes; as stated in item a) above generation of consistent cross sections is essential.

Finally, it is important to note that for the next phase of the design consistent detailed analyses will be required, and all the required design codes are already available and the design methods are validated. 


\section{REFERENCES}

1. Briesmeister, J.F. (1986) "MCNP - A General Monte Carlo Code for Neutron and Photon Transport (Version 3A)," LA-7396-M.

2. Derstine, K.L. (1984) "DIF3D: A Code to Solve One-, Two-, and ThreeDimensional Finite-Difference Diffusion Theory Problems," ANL-82-64.

3. Alcouffe, R.E., et al. (1987) "User's Guide for TWODANT: A Code Package for Two-Dimensional, Diffusion Accelerated, Neutral-Particle Transport," LA-10049-M.

4. Toppel, B.J. (1983) "A User's Guide for the REBUS-3 Fuel Cycle Analys is Capability," ANL-83-2.

5. VARI3D - Documentation in Progress

6. Clark, F.H. et al., "Physics Measurements on the SNAP Experimental Reactor (SER)," NAA-SR-5619.

7. Cobb, W.R., et al. (1975) "EPRI-CELL Code Description," EPRI-RP118-1.

8. Henryson, H. II, et a1. (1976) "Mc ${ }^{2}-2$ : A Code to Calculate Fast Neutron Spectra and Multigroup Cross Sections," ANL-8144 (ENDF-238).

9. MacFarlane, R.E., et al. (1982) "The NJOY Nuclear Data Processing System," LA-9303-M (ENDF-324).

10. Gunther, N.G. (1990) "Moderator Temperature Reactivity Coefficient for Incore Thermionic Reactor," SPI-CO-TDR-030690. 


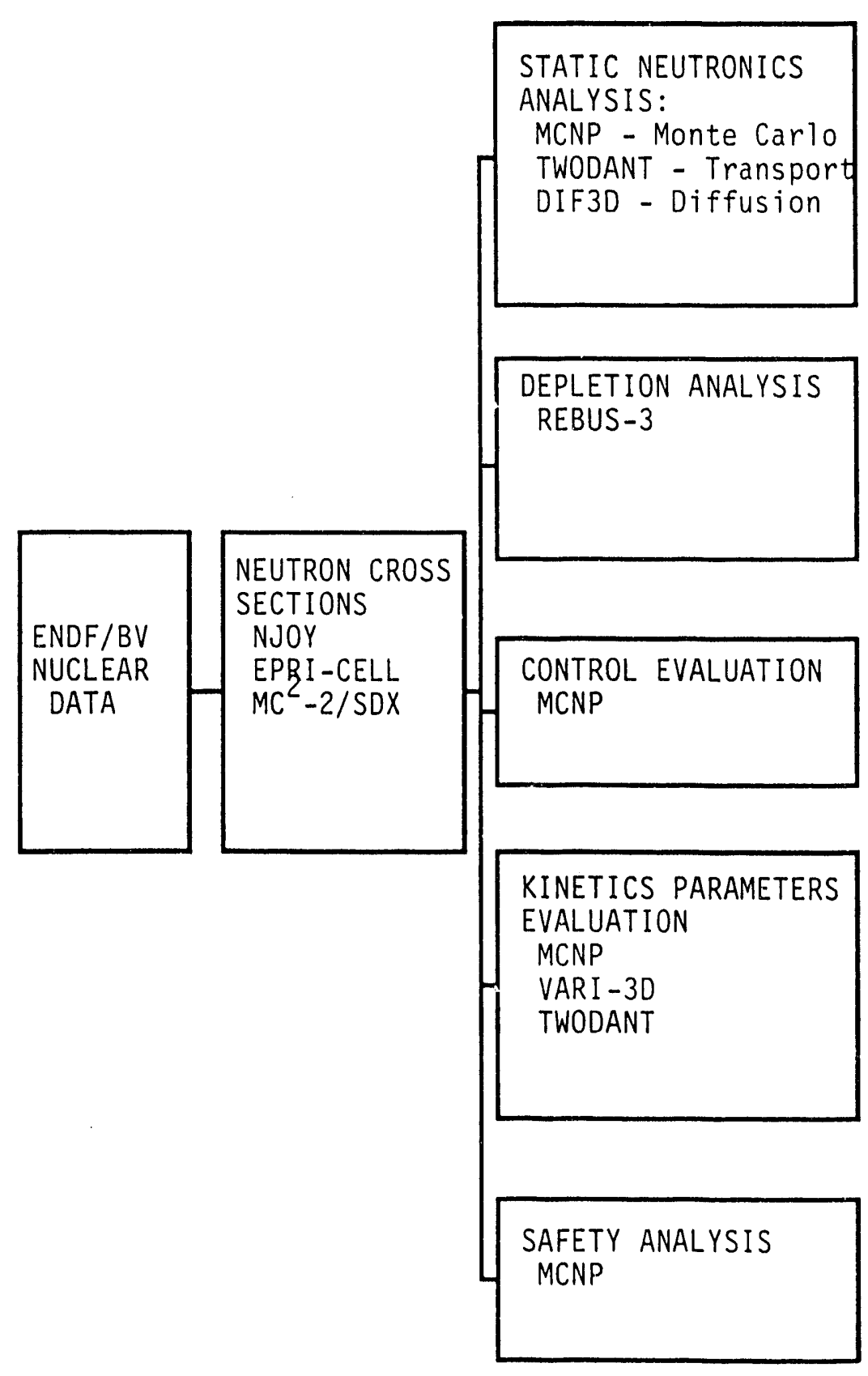

Fig. 1 Flowchart of Analytical Approach 


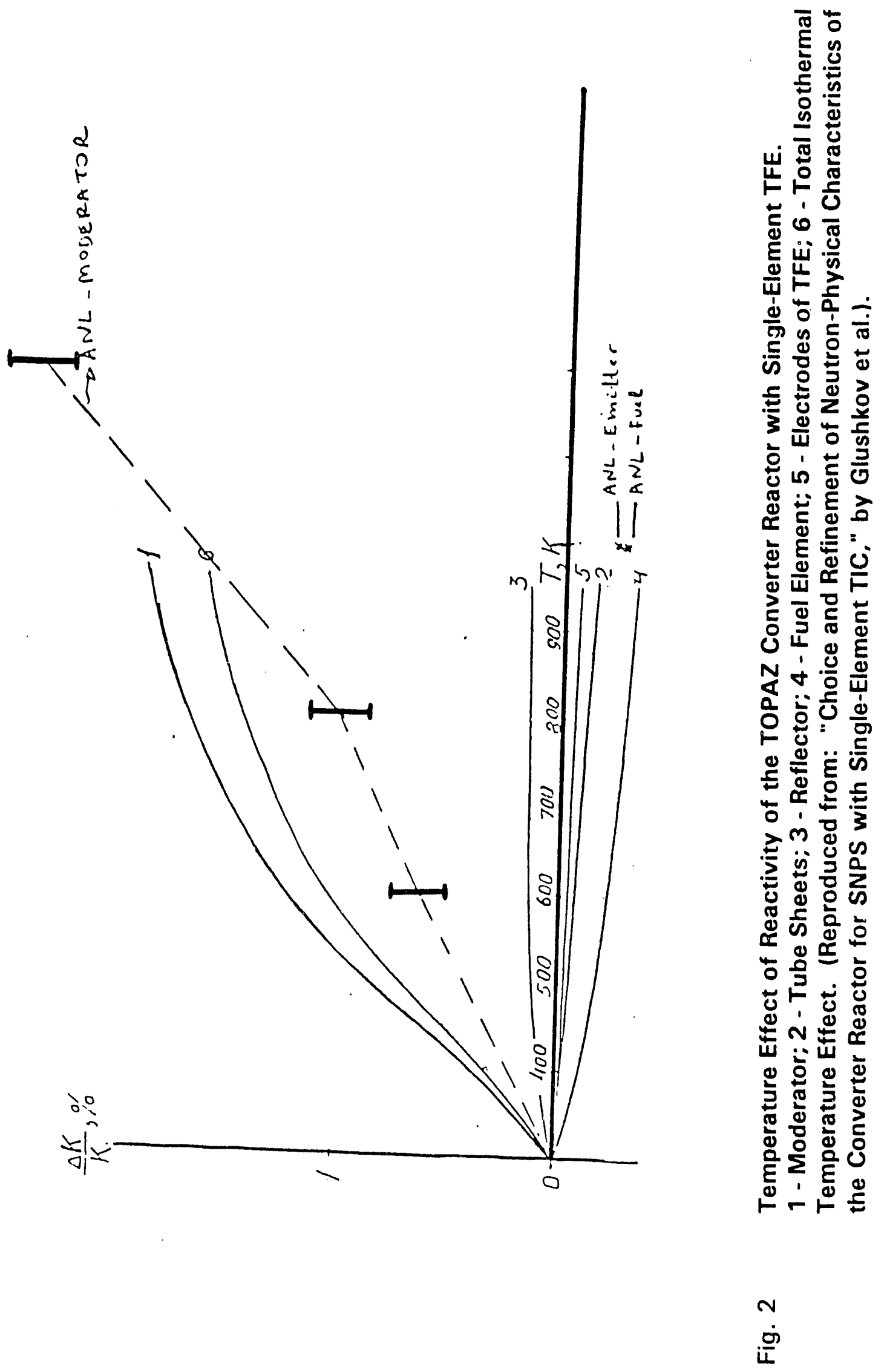




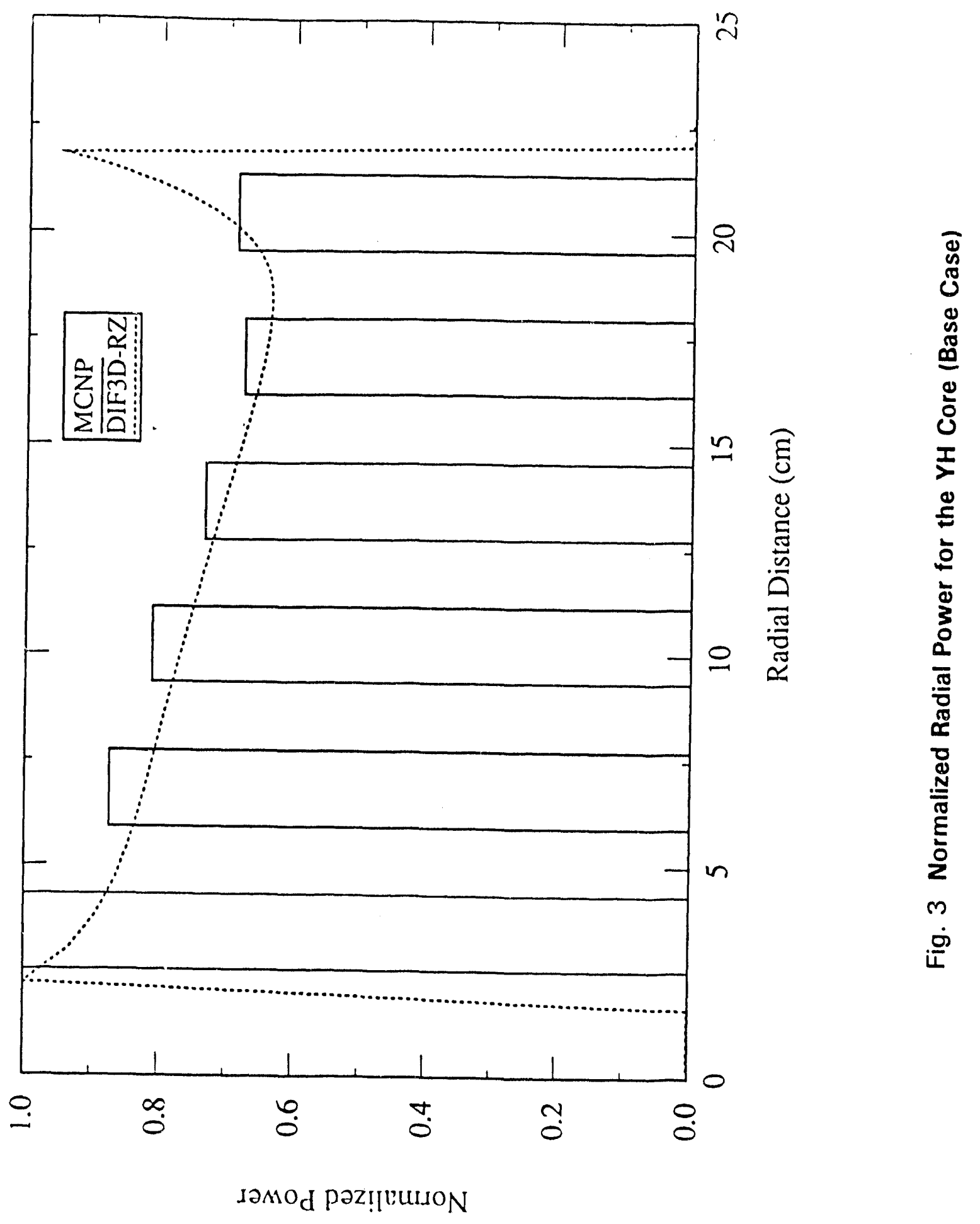




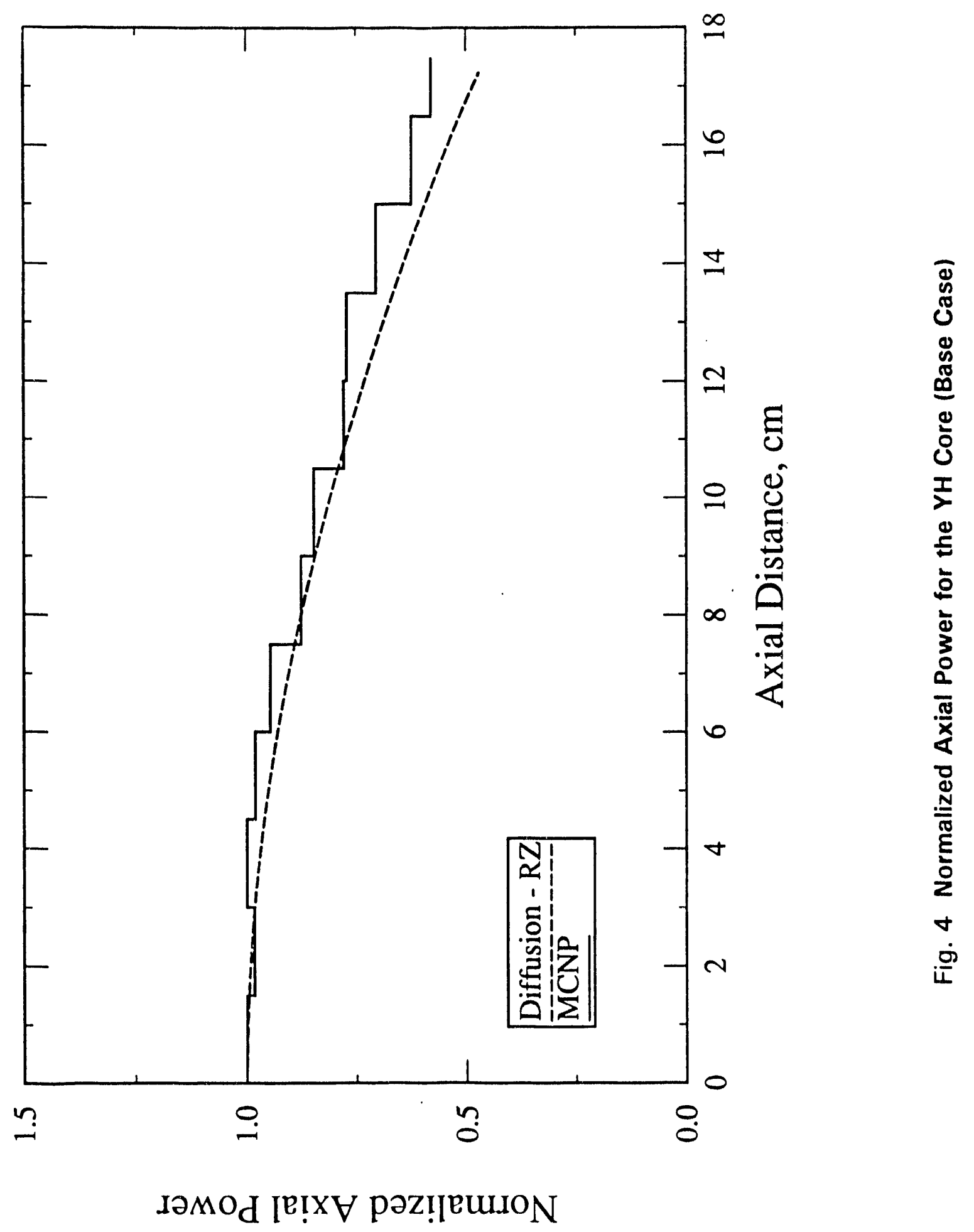




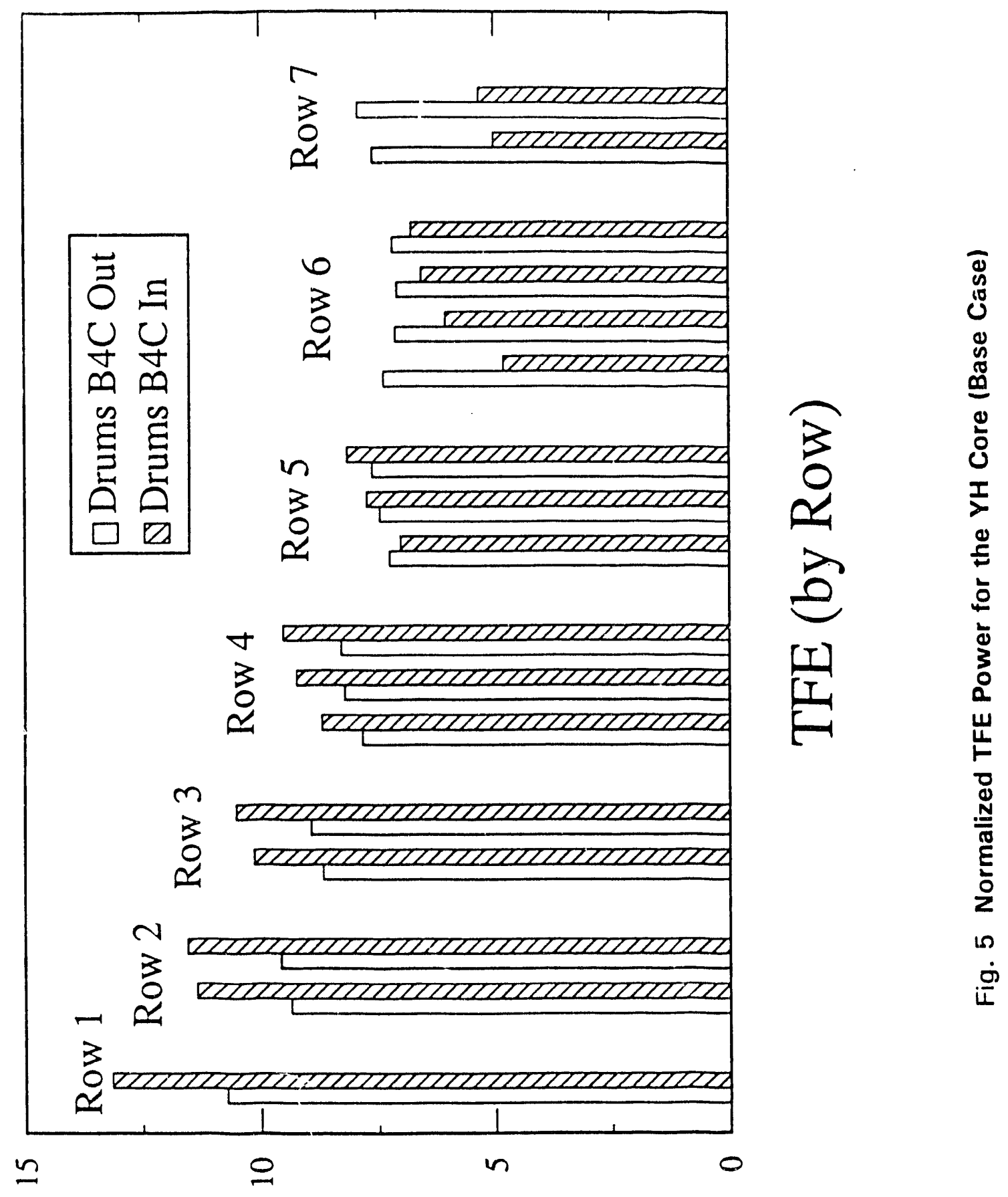

IOMOd pəz!ןeuIION 


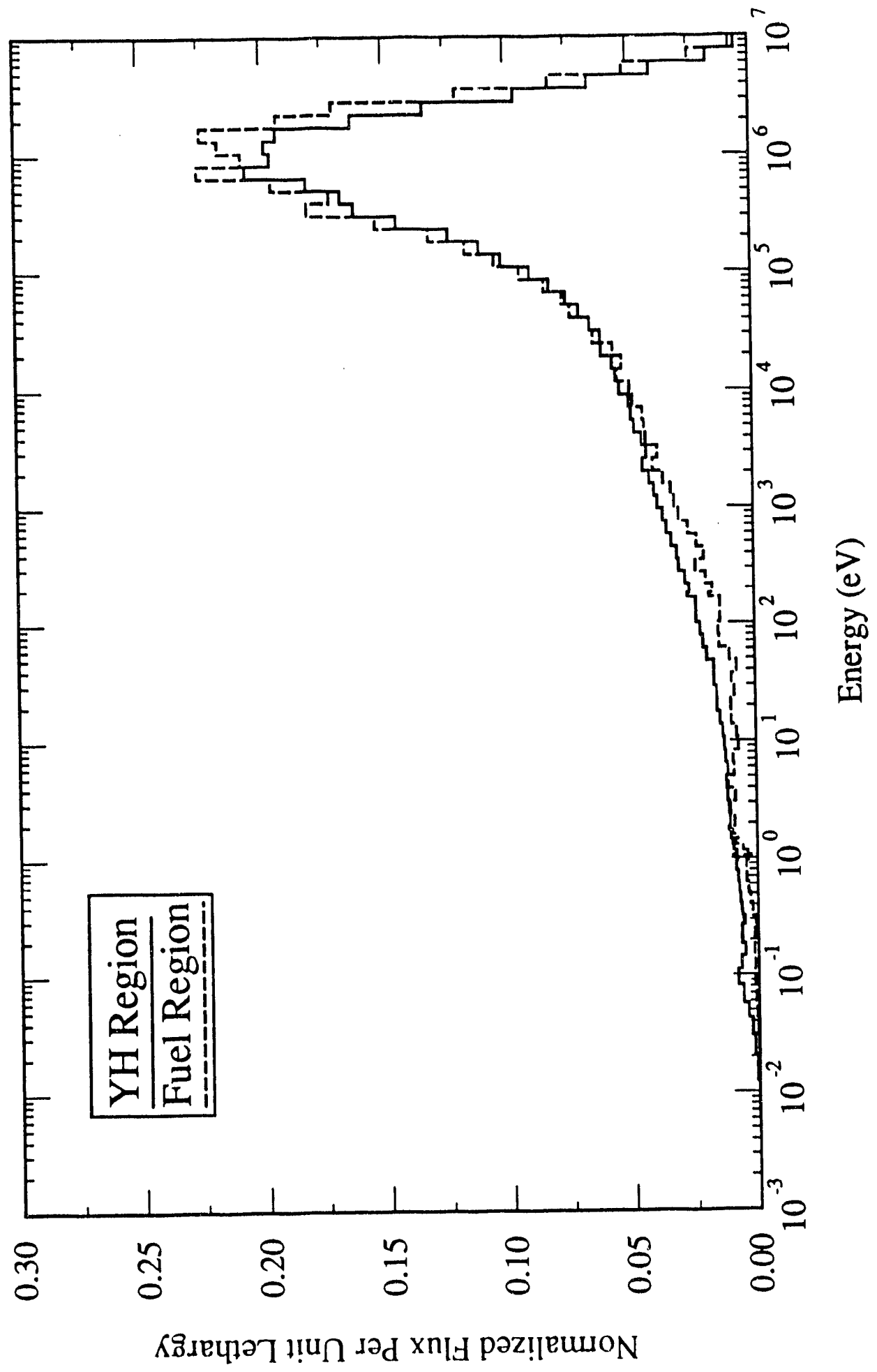

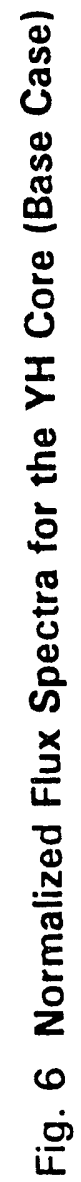




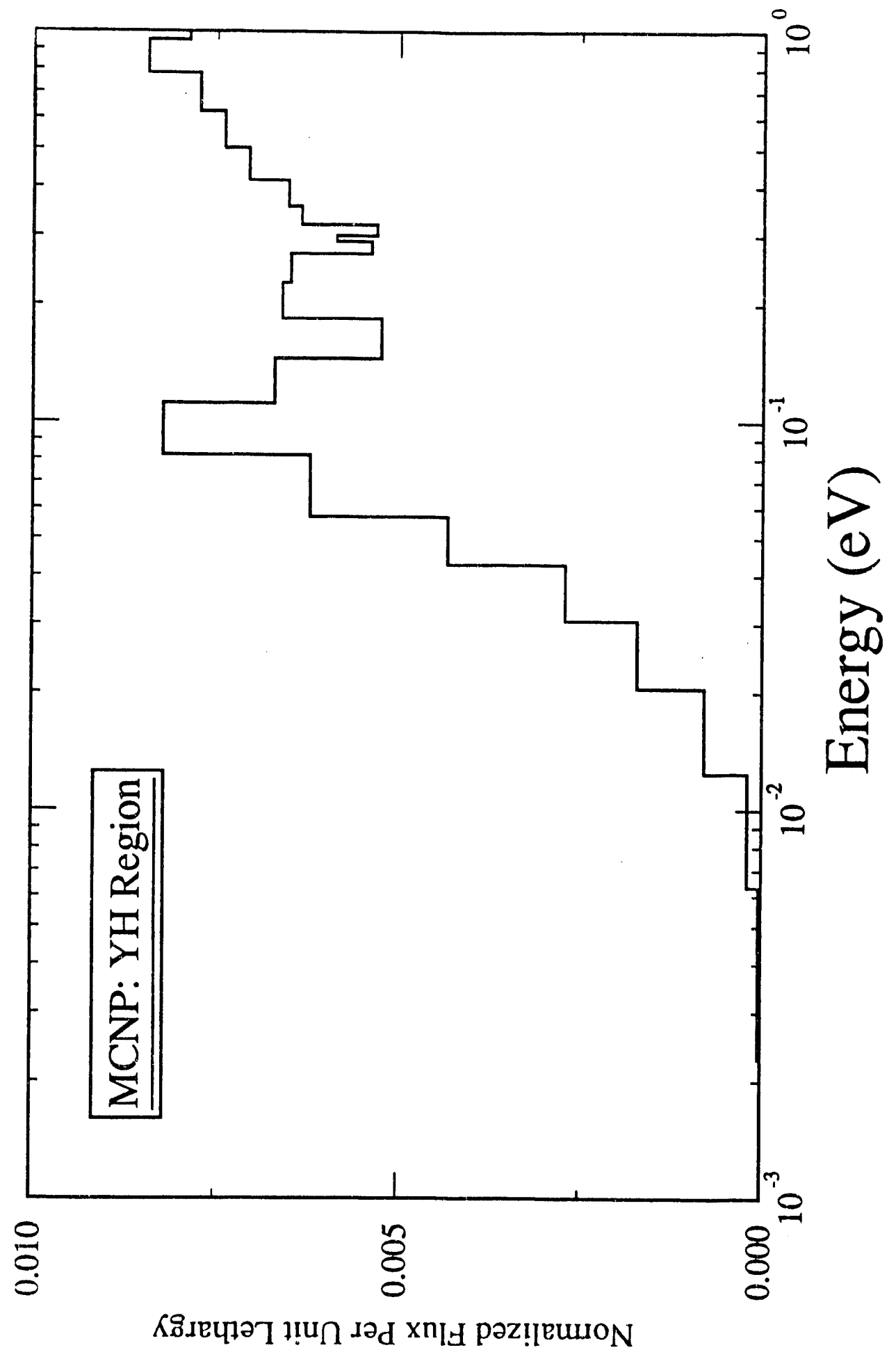

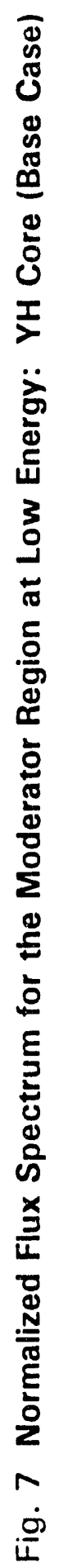




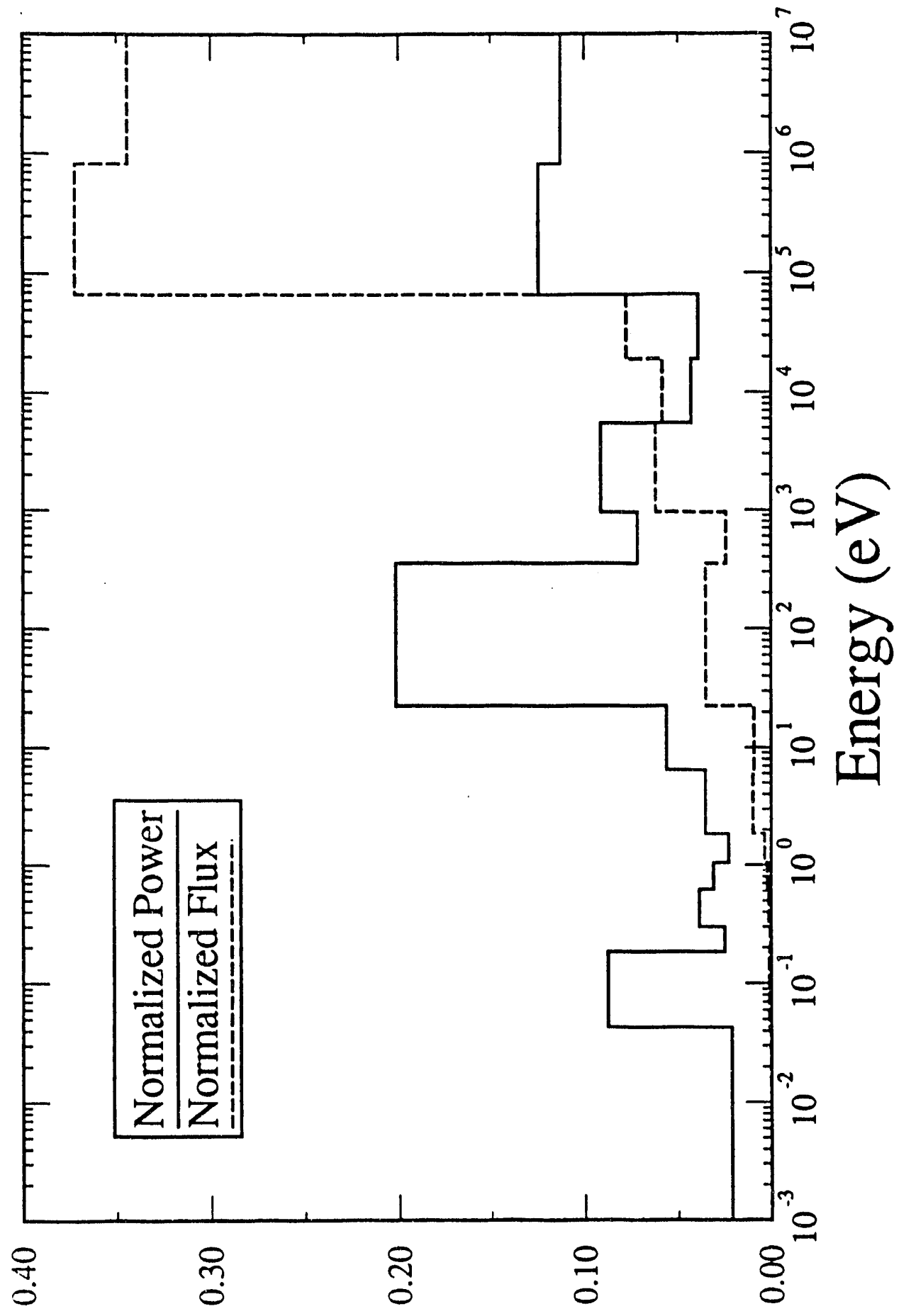

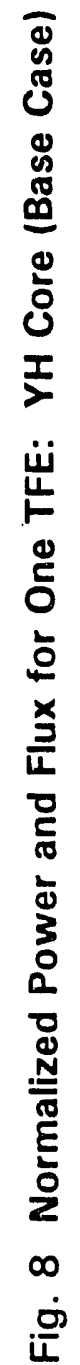




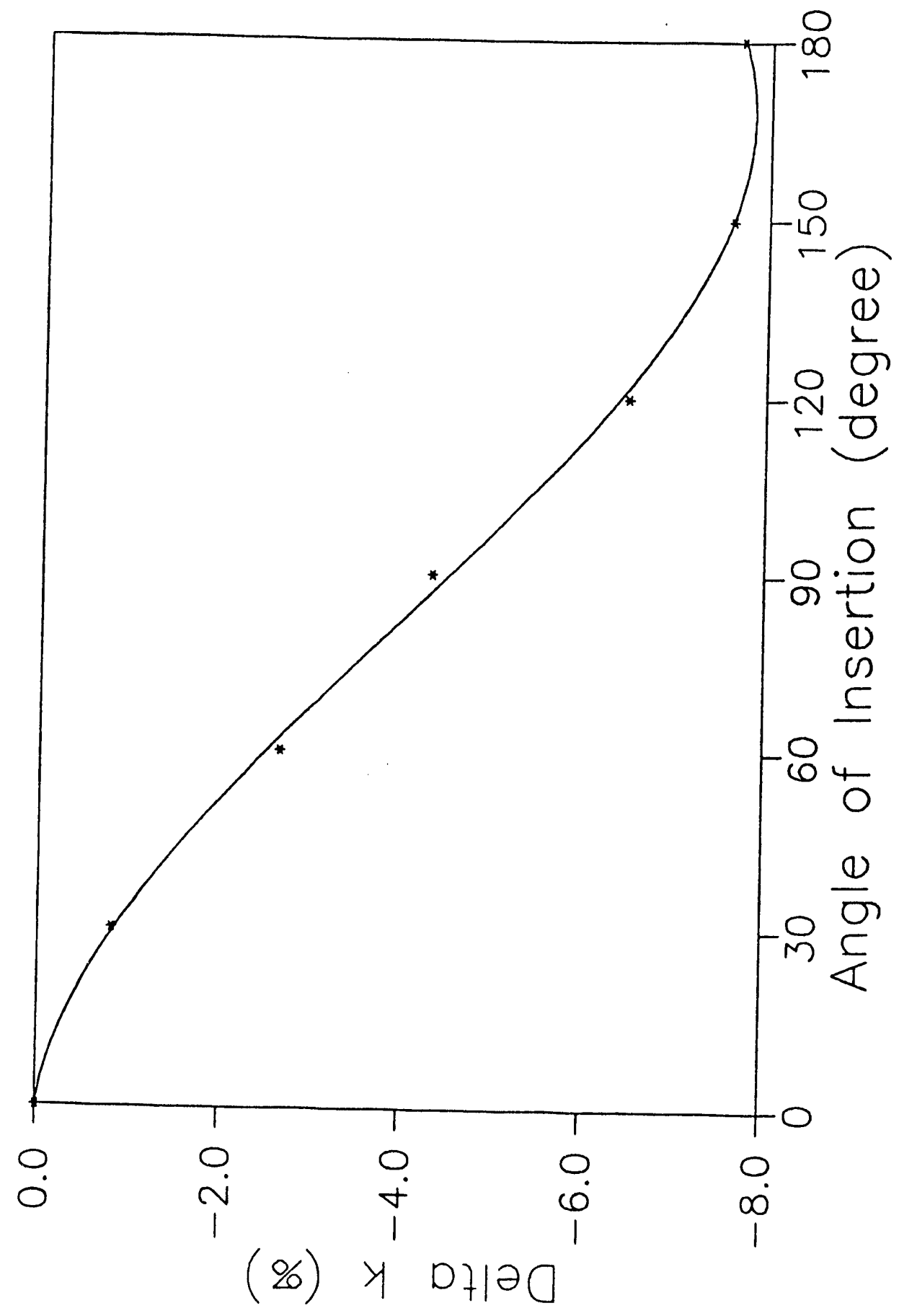

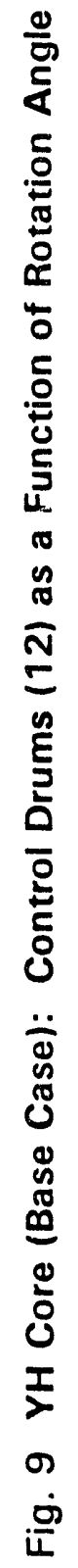




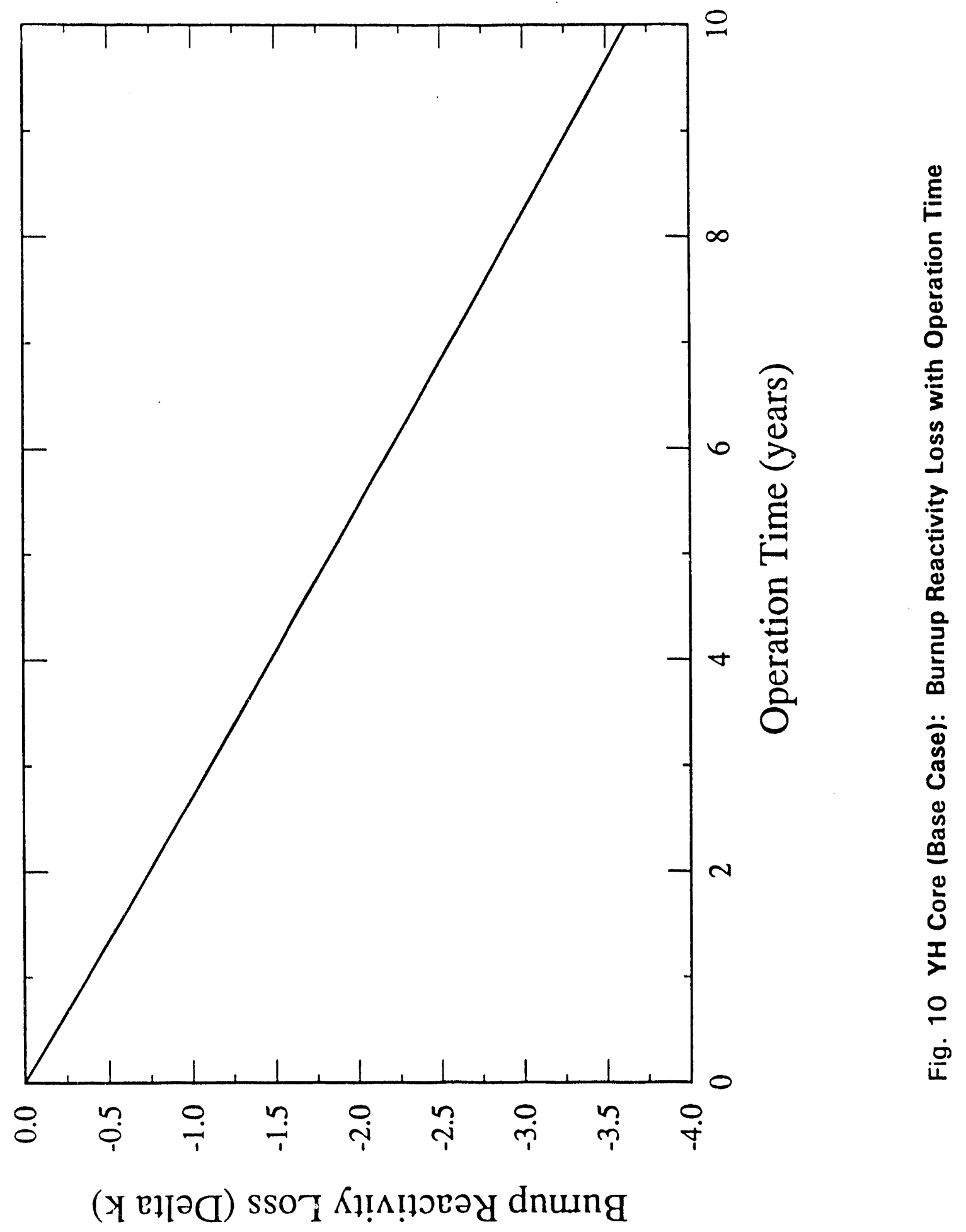




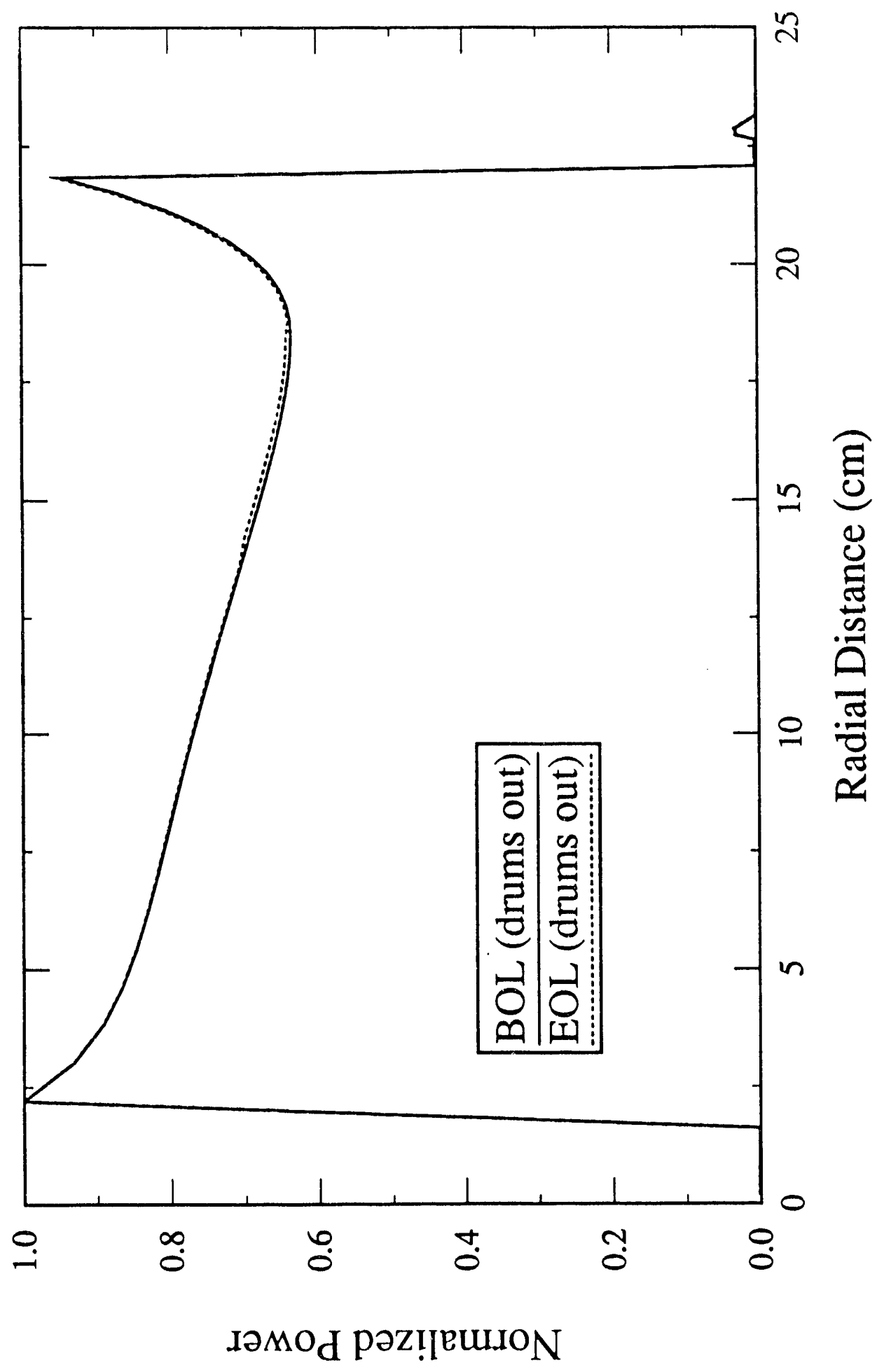

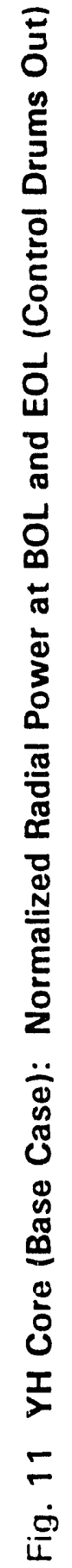




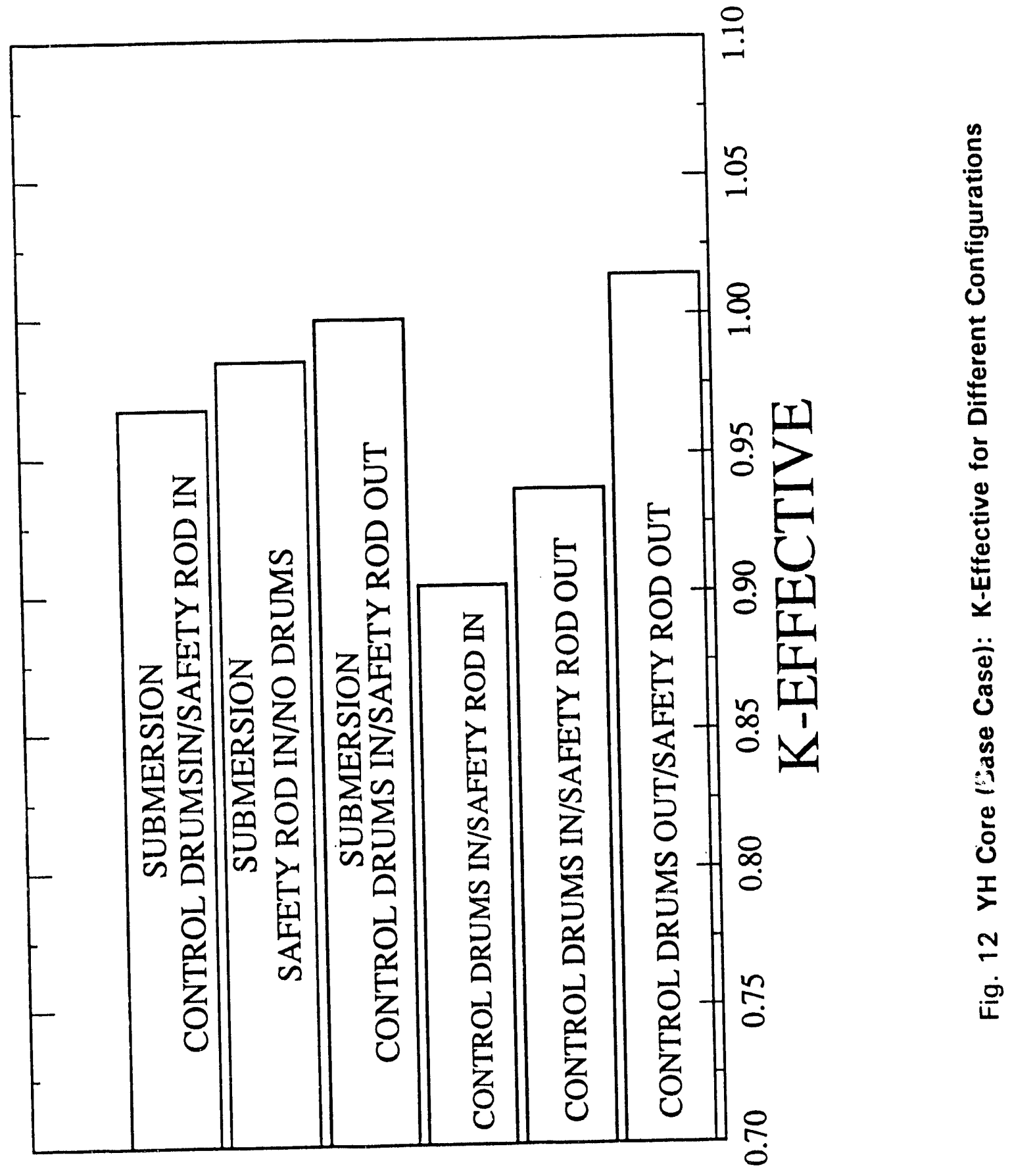


Table I. MCNP Cross Section Validation

A. Highly enriched $U$ metal spheres reflected by Beryllium (from LA-367-MS, Rev. - page 13)

\begin{tabular}{|c|c|c|c|}
\hline $\begin{array}{l}\text { Enrichment } \\
\left(\% \text { of } U^{235}\right)\end{array}$ & $\begin{array}{l}\text { Reflector } \\
\text { Thickness } \\
\text { (in.) }\end{array}$ & $\begin{array}{l}\text { Critical Mass } \\
\left(\mathrm{kg} \text { of } U^{235}\right)\end{array}$ & $\begin{array}{l}\text { MCNP } \\
k \text {-eff }\end{array}$ \\
\hline 93.9 & 1.84 & $22.2 \pm .02$ & $\begin{array}{l}0.996540 \pm 0.0012^{\star} \\
0.998996 \pm 0.0011^{\star \star}\end{array}$ \\
\hline 93.6 & 4.64 & $13.1 \pm .2$ & $\begin{array}{l}0.994496 \pm 0.0011^{\star} \\
1.000039 \pm 0.0012^{* *}\end{array}$ \\
\hline 93.9 & 1.89 & 21.6 & $0.996555 \pm 0.0010$ \\
\hline
\end{tabular}

B. SNAP Homogeneous Model with 55.2 fuel elements

(compositions and geometry from NAA-SR-5619)

$k($ MCNP $)=0.997072 \pm 0.0026$

* Critical Mass = Mean Value

** Critical Mass = Mean Value + One Sigma

Table II. 40 kWe Zirconium Hydride Core -

TFE Cross Section

\begin{tabular}{lccc}
\hline \multicolumn{1}{c}{ Region } & $\begin{array}{c}\text { OR } \\
(\mathrm{cm})\end{array}$ & Material & $\begin{array}{c}\text { Density } \\
(\mathrm{g} / \mathrm{cm})\end{array}$ \\
\hline Void & 0.569 & - & - \\
Fuel & 0.90 & UO 2 (90\% enr) & 10.95 \\
Emitter & 1.095 & Mo & 10.2 \\
Emitter & 1.10 & Nat. Tungsten & 19.1 \\
Gap & 1.13 & - & - \\
Collector & 1.23 & Mo & 10.2 \\
Gap & 1.27 & - & - \\
Sheath & 1.345 & Hastelloy w/O Tungsten & 9.0 \\
Coolant & 1.42 & NaK & 0.865 \\
Container & 1.47 & Hastelloy w/O Tungsten & 9.0 \\
Getter & 1.52 & Yttrium & 5.51 \\
Container & 1.57 & Hastelloy w/O Tungsten & 9.0 \\
\hline
\end{tabular}


Table III. 40 kWe Design Analysis Summary

\begin{tabular}{|c|c|c|}
\hline Core & Characteristics & Problems \\
\hline ZrH Moderated & Similar to TOPAZ & $\begin{array}{l}\text { - Not enough control with } \\
\text { drums } \\
\text { - } \quad \mathrm{H}_{2} \text { loss a problem } \\
\text { Large positive moderator } \\
\text { temperature coefficient }\end{array}$ \\
\hline $\begin{array}{l}\text { Be-ZrH Rod } \\
\text { Moderated }\end{array}$ & $\begin{array}{l}\mathrm{H}_{2} \text { loss reduction } \\
\text { with Be Cladding } \\
\text { Lower Positive } \\
\text { Moderator Temp. } \\
\text { Coefficient } \\
\text { Smaller Core possible }\end{array}$ & 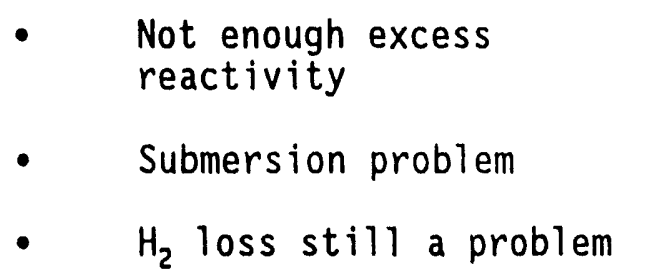 \\
\hline $\begin{array}{l}\text { Be-YH } \\
\text { Moderated: } \\
\text { Base Case }\end{array}$ & $\begin{array}{l}\text { - } \quad \text { No } \mathrm{H}_{2} \text { loss problem } \\
\text { Lower positive } \\
\text { moderator temp. } \\
\text { coefficient }\end{array}$ & $\begin{array}{l}\text { - } \quad \text { Not enough reactivity } \\
\text { - } \quad \text { Submersion problem }\end{array}$ \\
\hline $\begin{array}{l}\text { Be-YH } \\
\text { Moderated: } \\
\text { Mod. } 1\end{array}$ & $\begin{array}{l}\text { Same as above, but: } \\
\text { Increased Fuel smear } \\
\text { density ( } 73 \%) \\
\text { Detailed Axial } \\
\text { reflector (with void } \\
\text { region) }\end{array}$ & $\begin{array}{l}\text { - } \quad \text { Not enough reactivity } \\
\text { - } \quad \text { Submersion problem }\end{array}$ \\
\hline $\begin{array}{l}\text { Be-YH } \\
\text { Moderated: } \\
\text { Mod. } 2\end{array}$ & $\begin{array}{l}\text { Same as above, but: } \\
\text { - } \quad 70 \% \text { fuel smear } \\
\text { density } \\
\text { Detailed axial } \\
\text { reflector with Be } \\
\text { replacing void region } \\
\text { - Uses Gadolinia rods }\end{array}$ & $\begin{array}{l}\text { - Submersion problem } \\
\text { (solution feasible but requires } \\
\text { iterative analysis not } \\
\text { performed because of level of } \\
\text { effort constraints) }\end{array}$ \\
\hline
\end{tabular}


Table IV. 40 kWe Zirconium Hydride Core Core Characteristics

\begin{tabular}{ll}
\hline Number of TFEs & 151 \\
Hexagonal Pitch $(\mathrm{cm})$ & 3.85 \\
Equivalent Core Diameter $(\mathrm{cm})$ & 52.2 \\
Core active Length (cm) & 35.0 \\
$U^{235}$ Fuel Loading (kg) & 70.0 \\
$U^{235}$ Enrichment (\%) & 90 \\
Fuel Smear Density (\%) & 60 \\
Moderator & Zrh \\
Radial Reflector & Be \\
Material & 10 \\
Thickness (cm) & \\
Axial Reflector & Homogeneous Mixture of: Mo, Be, \\
Material & SS316L, and NaK \\
Thickness (cm) & 10 \\
Control Drums & 12 \\
Number & 10.4 \\
Diameter (cm) & Be with $1 \mathrm{~cm}$ lens of $90 \%$ enriched \\
Material & B C
\end{tabular}

Table V. 40 kWe Zirconium Hydride Core Cross Section Validation

\begin{tabular}{lll}
\hline I. Core Analysis (with $\mathrm{H}_{2}$ loss) & \\
MCNP & $1.040672 \pm 0.0018$ \\
RZ Diffusion/15 Group XS & 1.04482 \\
MCNP/RZ & 0.99603 \\
& \\
II. Unit Cell Analysis & $1.420184 \pm 0.0012$ \\
MCNP & 1.402437 \\
Transport (S3P8)/97 Groups & 1.01265 \\
MCNP/Transport & \\
\hline
\end{tabular}


Table VI. 40 kWe Zirconium Hydride Core Control Drums Worth

\begin{tabular}{lll}
\hline Drums Out & $1.046988 \pm 0.0023$ & \\
Drums In & $1.024777 \pm 0.0027$ & \\
& & \\
Drums Worth (Delta k \%) & & 2.22 \\
\hline
\end{tabular}

Table VII. 40 kWe Zirconium Hydride Core Moderator Temperature Coefficient

(MCNP Analysis/Core Mode1/No Drums or Vessel/With $10 \mathrm{w}^{2} \mathrm{H}_{2}$ Loss)

Case 1: $\mathrm{ZrH}$ at $300 \mathrm{~K}$

$k=1.039645 \pm .0011$

Case 2: $\mathrm{ZrH}$ at $600 \mathrm{~K}$

$k=1.046198 \pm .0009$

$(\Delta K / K) /{ }^{\circ} K=2.101 E-5$ (from 300 to $\left.600 K\right)^{a}$

Case 3: $\mathrm{ZrH}$ at $800 \mathrm{~K}$

$k=1.050015 \pm .0010$

$(\Delta \mathrm{k} / \mathrm{K}) /{ }^{\circ} \mathrm{K}=1.824 \mathrm{E}-5(\text { from } 600 \text { to } 800 \mathrm{~K})^{\mathrm{a}}$

Case 4: $\mathrm{ZrH}$ at $1200 \mathrm{~K}$

$k=1.064441 \pm .0010$

$(\Delta \mathrm{k} / \mathrm{K}) /{ }^{\circ} \mathrm{K}=3.435 \mathrm{E}-5$ (from 800 to $1200 \mathrm{~K}$ )

mean value

Table VIII. 40 kWe Zirconium Hydride Core -

Temperature Reactivity Coefficients $\left[(\Delta \mathrm{k} / \mathrm{k}) /{ }^{\circ} \mathrm{K}\right]$

\begin{tabular}{cc}
\hline Doppler: & \\
Fue1 & $-3.94 \mathrm{E}-6$ \\
Emitter: & \\
Mo & $-2.49 \mathrm{E}-6$ \\
W & $-1.06 \mathrm{E}-6$ \\
(Mo $+\mathrm{W})$ & $-3.54 \mathrm{E}-6$ \\
\hline
\end{tabular}


Table IX. 40 kWe Zirconium Hydride Core - Neutron Kinetics Parameters

\begin{tabular}{ccc}
$\begin{array}{c}\text { Delayed Neutron } \\
\text { Group } i\end{array}$ & Beta & $\begin{array}{c}\text { Lambda } \\
1 / \text { SEC }\end{array}$ \\
\hline 1 & $2.7532 \mathrm{E}-4$ & $1.2720 \mathrm{E}-2$ \\
2 & $1.5325 \mathrm{E}-3$ & $3.1740 \mathrm{E}-2$ \\
3 & $1.3523 \mathrm{E}-3$ & $1.1600 \mathrm{E}-1$ \\
4 & $2.9283 \mathrm{E}-3$ & $3.1100 \mathrm{E}-1$ \\
5 & $9.2095 \mathrm{E}-4$ & $1.4000 \mathrm{E}+0$ \\
6 & $1.8707 \mathrm{E}-4$ & $3.8700 \mathrm{E}+00$ \\
\hline TOTAL & $7.1965 \mathrm{E}-3$ & \\
\hline
\end{tabular}
$\begin{array}{ll}\text { - Neutron Generation Time: } & 2.640 \mathrm{E}-06 \mathrm{sec} \\ \text { Prompt Lifetime: } & 2.752 \mathrm{E}-06 \mathrm{sec} \\ \text { - Effective Delayed Neutron Lifetime: } & 1.274 \mathrm{E}+01 \mathrm{sec} \\ \text { The effect of photoneutrons from Be is not accounted for in these } \\ \text { calculations. }\end{array}$

Table X. 40 kWe Rod Moderated Core - TFE Cross Section

\begin{tabular}{lccc}
\hline \multicolumn{1}{c}{ Region } & OR $(\mathrm{cm})$ & Material & Density $(\mathrm{g} / \mathrm{cm})$ \\
\hline Void & 0.5375 & -- & - \\
Fuel & 0.85 & $\mathrm{UO}_{2}(90 \%$ enr $)$ & 10.95 \\
Emitter & 0.995 & Mo & 10.2 \\
Emitter & 1.00 & Nat Tungsten & 19.1 \\
Gap & 1.03 & - & - \\
Sheath & 1.245 & SS316L & 7.9 \\
\hline
\end{tabular}

Table X1. 40 kWe Rod Moderated Core - Moderated Rod Cross Section

\begin{tabular}{lccc}
\hline \multicolumn{1}{c}{ Region } & OR $(\mathrm{cm})$ & Material & Density $(\mathrm{g} / \mathrm{cm})$ \\
\hline Hydride & 0.968 & $\mathrm{ZrH}$ & 5.5 \\
Beryllium & 1.1675 & Be & 1.85 \\
Gap & 1.20 & - & - \\
$\mathrm{Clad}$ & 1.25 & Hastelloy w/0 & 9.0 \\
\hline
\end{tabular}


Table XII. 40 kWe Rod Moderated Core - Core Characteristics

\begin{tabular}{|c|c|c|}
\hline Number of TFEs & 151 & \\
\hline $\begin{array}{l}\text { Number of Moderator Rods } \\
\text { Pitch }(\mathrm{cm})\end{array}$ & 120 & 2.525 \\
\hline Equivalent Core Diameter $(\mathrm{cm})$ & 44.2 & \\
\hline Core Active Length $(\mathrm{cm})$ & 35.0 & \\
\hline$U^{235}$ Fuel Loading (kg) & 78.2 & \\
\hline$U^{235}$ Enrichment (\%) & 90 & \\
\hline Fuel Smear Density (\%) & 60 & \\
\hline Moderator & $\mathrm{ZrH}+$ & $\mathrm{Be}$ \\
\hline $\begin{array}{l}\text { Radial Reflector } \\
\text { Material } \\
\text { Thickness }(\mathrm{cm})\end{array}$ & & $\begin{array}{l}\text { Be } \\
10\end{array}$ \\
\hline $\begin{array}{c}\text { Axial Reflector } \\
\text { Material }\end{array}$ & & $\begin{array}{l}\text { Homogeneous Mixture } \\
\text { of: } \\
\text { Mo, Be, SS316L, and } \\
\text { NaK } \\
10\end{array}$ \\
\hline $\begin{array}{c}\text { Control Drums } \\
\text { Number } \\
\text { Diameter }(\mathrm{cm}) \\
\text { Material }\end{array}$ & & $\begin{array}{l}12 \\
10.4 \\
\text { Be with } 1 \mathrm{~cm} \text { of } 90 \% \\
\text { enriched } \mathrm{B}_{4} \mathrm{C}\left(120^{\circ}\right. \\
\text { arC })\end{array}$ \\
\hline Interstitial Material & $\mathrm{Be}+$ & SS316L + NaK \\
\hline
\end{tabular}


Table XIII. 40 kWe Rod Moderated Core - Control Drums Worth

$\begin{array}{ll}\text { Drums out } & k=1.018531 \pm 0.0011 \\ \text { Drums In } & k=0.951172 \pm 0.0023\end{array}$

Drums Worth $(\Delta k \%)$

TABLE XIV. 40 kWe Rod Moderated Core - Submersion Analysis

- Water Replaces NaK in Core and Axial Reflector

- Water Surrounds Reactor

- Base Case: $k=1.018531 \pm 0.0011$

\begin{tabular}{lc}
\hline \multicolumn{1}{c}{ Configuration } & k-Effective \\
\hline Normal Configuration/No Water & $1.018531 \pm 0.0011$ \\
Drums In/Water Replaces NaK/Water Around Axial & \\
and Radial Reflector & $1.025277 \pm 0.0021$ \\
Drums In/Safety Rod In/Water Replaces & \\
Nak/Water Around Axial and Radial Reflector & $0.997932 \pm 0.0021$ \\
\hline & \\
\hline & Submersion Problem
\end{tabular}

Table XV. 40 kWe Rod Moderated Core - Sensitivity Study

\begin{tabular}{lr}
\hline Base Case: Enrichment $=90 \% \mathrm{U}^{235}$ & \\
Radial Reflector $=10 \mathrm{~cm}$ Be (between & $\mathrm{k}=1.018531 \pm 0.0011$ \\
peaks) & \\
Case 1: Enrichment $=97 \%$ & $\mathrm{k}=1.038257 \pm 0.0023$ \\
& $\Delta \mathrm{k}=0.019726 \pm 0.0026$ \\
Case 2: Enrichment $=97 \%$ & \\
Radial reflector thickness increased to & $k=1.045312 \pm 0.0018$ \\
$10 \mathrm{~cm}$ between flats & $\Delta \mathrm{k}=0.026781 \pm 0.0021$ \\
\hline
\end{tabular}


Table XVI. 40 kWe Rod Moderated Core Moderator/Reflector Temperature Reactivity Coefficierits $\left[(\Delta \mathrm{k} / \mathrm{k}) /{ }^{\circ} \mathrm{K}\right]$

\begin{tabular}{|c|c|}
\hline Base Case (a11 at $300 \mathrm{~K}$ ) & $k=1.018531 \pm 0.0011$ \\
\hline Moderator ( $\mathrm{ZrH}$ and $\mathrm{Be}$ ) at $800 \mathrm{~K}$ & $\begin{aligned} k & =1.024548 \pm 0.0011 \\
\Delta k & =0.006017 \pm 0.0016\end{aligned}$ \\
\hline Radial Reflector $(\mathrm{Be})$ at $800 \mathrm{~K}$ & $\begin{aligned} k & =1.020466 \pm 0.0011 \\
\Delta k & =0.001935 \pm 0.0016\end{aligned}$ \\
\hline \multicolumn{2}{|c|}{$\begin{array}{l}\text { *Uncertainty still too large compared with } \Delta k \text { values; calculation to } \\
\text { decrease uncertainty not performed because concept was dropped from } \\
\text { consideration. }\end{array}$} \\
\hline
\end{tabular}

Table XVII. 40 kWe Yttrium Hydride Core - Core Characteristics

\begin{tabular}{|c|c|}
\hline $\begin{array}{l}\text { Number of TFEs } \\
\text { Pitch }(\mathrm{cm})\end{array}$ & $\begin{array}{l}150 \\
3.4125\end{array}$ \\
\hline Equivalent Core Diameter $(\mathrm{cm})$ & 45.4 \\
\hline Core Active Length $(\mathrm{cm})$ & 35.0 \\
\hline$U^{235}$ Fue1 Loading $(\mathrm{kg})$ & 69.5 \\
\hline$U^{235}$ Enrichment (\%) & 90 \\
\hline Fuel Smear Density (\%) & 60 \\
\hline Moderator & $\mathrm{YH}+\mathrm{Be}$ \\
\hline $\begin{array}{l}\text { Radial Reflector } \\
\text { Material } \\
\text { Thickness (cm) }\end{array}$ & $\begin{array}{l}\mathrm{Be} \\
10\end{array}$ \\
\hline $\begin{array}{c}\text { Axial Reflector } \\
\text { Material }\end{array}$ & $\begin{array}{l}\text { Homogeneous Thickness }(\mathrm{cm}) \text { Mixture of: } \\
\text { Mo, Be, SS316L, and NaK }\end{array}$ \\
\hline $\begin{array}{l}\text { Control Drums } \\
\text { Number } \\
\text { Diameter }(\mathrm{cm}) \\
\text { Material }\end{array}$ & $\begin{array}{l}12 \\
10.4 \\
\text { Be with } 1 \mathrm{~cm} \text { lens of } 90 \% \text { enriched } \mathrm{B}_{4} \mathrm{C}\end{array}$ \\
\hline $\begin{array}{l}\text { Safety Rod } \\
\text { Follower Material } \\
\text { Poison }\end{array}$ & $\begin{array}{l}\mathrm{Be} \\
90 \% \text { enriched } \mathrm{B}_{4} \mathrm{C}\end{array}$ \\
\hline
\end{tabular}


Table XVIII. 40 kWe Yttrium Hydride Core - TFE Cross Section

\begin{tabular}{lccc}
\hline \multicolumn{1}{c}{ Region } & OR $(\mathrm{cm})$ & Material & Density $(\mathrm{g} / \mathrm{cm})$ \\
\hline Void & 0.5692 & -- & - \\
Fuel & 0.90 & $\mathrm{UO}_{2}$ (90\% enr) & 10.95 \\
Emitter & 1.0375 & Mo & 10.2 \\
Emitter & 1.05 & W $(2 \text { pass })^{1}$ & 19.1 \\
Gap & 1.08 & - & - \\
Collector & 1.18 & Mo & 10.2 \\
Gap & 1.22 & - & - \\
Sheath & 1.30 & SS316L & 7.9 \\
Coolant & 1.375 & NaK & 0.865 \\
Clad for Be & 1.40 & SS316L & 7.9 \\
Be Moderator & 1.55 & $\mathrm{Be}$ & 1.85 \\
\hline
\end{tabular}

Table XIX. 40 kWe Yttrium Hydride Core - Central Control Rod

\begin{tabular}{lccc}
\hline \multicolumn{1}{c}{ Region } & OR $(\mathrm{cm})$ & Material & Density $(\mathrm{g} / \mathrm{cm})$ \\
\hline Follower & 1.3 & Be & 1.85 \\
Poison & 1.3 & $B_{4} C(90 \%$ enr $)$ & 2.5 \\
Coolant & 1.375 & NaK & 0.865 \\
Clad & 1.4 & SS316L & 7.9 \\
Be & 1.55 & Be & 1.85 \\
\hline
\end{tabular}

Table XX. 40 kWe Yttrium Hydride Core - Control Drums/Safety Rod Worth

\begin{tabular}{lll}
\hline Drums Out/Safety Rod Out & $1.014147 \pm 0.0007$ & \\
Drums In/Safety Rods Out & $0.937389 \pm 0.0017$ & 7.68 \\
Drums Worth $(\Delta \%)$ & $0.986213 \pm 0.0016$ & 2.79 \\
Drums Out/Safety Rod In \\
$\begin{array}{l}\text { Safety Rod Worth }(K \%) \\
\text { Drums In/Safety Rod In } \\
\begin{array}{l}\text { Drums Plus Safety Rod } \\
\text { Worth (\%) }\end{array}\end{array}$ & $0.902900 \pm 0.0016$ & \\
\hline
\end{tabular}

$1 W-182 / W-183 / W-184 / W-186=1 / 18 / 80 / 1$ (weight \%) 
Table XXI. 40 kWe Yttrium Hydride Core - Cross Section Validation

I. Core Analysis

MCNP $\quad 1.014147 \pm 0.0005$

RZ Diffusion/15 Group XS $\quad 1.017136$

II. Unit Cell Analysis

MCNP $\quad 1.550869 \pm 0.0007$

Transport (P3S8)/97 Groups $\quad 1.535071$

Table XXII. 40 kWe Yttrium Hydride Core -

Temperature Reactivity Coefficients

$\left[(\Delta \mathrm{k} / \mathrm{k}) /^{\circ} \mathrm{K}\right]$

\begin{tabular}{cc}
\hline Moderator $(\mathrm{YH}+\mathrm{Be})^{1}$ & $+3.1 \mathrm{E}-6$ \\
Radial Reflector $\mathrm{Be})^{2}$ & $+3.9 \mathrm{E}-6$ \\
Doppler: & \\
Fuel & $-4.1 \mathrm{E}-6$ \\
Emitter: & $-2.4 \mathrm{E}-6$ \\
Mo & $-6.8 \mathrm{E}-7$ \\
(Mo + W) & $-3.1 \mathrm{E}-6$ \\
(Collector + Sheath) Mo & $-2.4 \mathrm{E}-6$ \\
\hline
\end{tabular}

'MCNP Analysis/Reactor Core Mode1/Temperature Range: 300 to 800K/Mean Value Reported

${ }^{2}$ Same as above

${ }^{3} 1-D$ Transport (P3S8) Unit Ce11/97-Group XS generated for the $40 \mathrm{kWe} \mathrm{ZrH}$ Moderated Core/Temperature Range: 300 to $1000 \mathrm{~K}$ 
Table XXIII. 40 kWe Yttrium Hydride Core Summary of Reactivity Requirements

\begin{tabular}{|c|c|}
\hline Burnup Reactivity Swing & +3.62 \\
\hline $\begin{array}{l}\text { TFE Doppler: } \\
\text { Fuel }(300 \text { to } 1908 \mathrm{~K}) \\
\text { Emitter }(300 \text { to } 1850 \mathrm{~K}) \\
\text { (Collector + Sheath) Mo } \\
(300 \text { to } 1500 \mathrm{~K})\end{array}$ & $\begin{array}{l}+0.66 \\
+0.48 \\
+0.29\end{array}$ \\
\hline Moderator $(300$ to $800 \mathrm{~K})$ & -0.15 \\
\hline Radial Reflector (300 to $800 \mathrm{~K}$ ) & -0.20 \\
\hline One Stuck Drum & +0.64 \\
\hline $\begin{array}{l}\text { Uncertainties (minimum) } \\
\text { Subtotal }\end{array}$ & $\begin{array}{l}+1.00+6.34\end{array}$ \\
\hline Radial Expansion & TBD \\
\hline Axial Expansion & TBD \\
\hline Axial Reflector & TBD \\
\hline Coolant & TBD \\
\hline Power Shaping Reactivity & TBD \\
\hline Total & TBD \\
\hline
\end{tabular}


Table XXIV. 40 kWe Yttrium Hydride Core - Sensitivity Study

Base Case:

Enrichment $=90 \% U^{235}$

$k=1.014147 \pm 0.0007$

Radial Reflector $=10 \mathrm{~cm} \mathrm{Be}$ Collector $=$ Mo

Case 1: Enrichment $=97 \%$

$k=1.036640 \pm 0.0011$

$\Delta k=0.02493 \pm 0.0017$

Case 2: Enrichment $=97 \%$ Weight Fraction in Homogeneous

Axial Reflector:

Case 2a: Increase Be by $10 \%$ (decrease Mo by $10 \%$ ) Case 2b: Increase Be by $20 \%$ (decrease Mo by $20 \%$ )

$k=1.052253 \pm 0.0020$

$\Delta k($ Case 2a-Case 1$)=0.15610 \pm$ 0.0025

$k=1.062592 \pm 0.0018$ $\Delta \mathrm{k}($ Case 2b-Case 1) $=0.025950 \pm$ 0.0024

Case 3: Increase Radial Reflector Thickness to $12 \mathrm{~cm}$

$k=1.027589 \pm 0.0018$ $\Delta k=0.013451 \pm 0.0019$

Case 4: Replace Mo by $\mathrm{Nb}$ in $k=1.005753 \pm 0.0015$ Collector $\Delta k=-0.008354 \pm 0.0016$

Case 5: Replace Homogeneous Axial Reflector by Detailed Axial

$k=1.012573 \pm 0.0020$ Reflector

'Uncertainty too large when compared with $\Delta k$ 
Table XXV. 40 kWe Yttrium Hydride Core - Submersion Analysis

- Water Replaces NaK in Core and Axial Reflector

- Water Surrounds Reactor

- Base Case: $k=1.014147 \pm 0.0007$

\begin{tabular}{lc}
\hline \multicolumn{1}{c}{ Configuration } & k-Effective \\
\hline Normal Configuration/No Water & $1.014147 \pm 0.0007$ \\
$\begin{array}{l}\text { Drums In/Safety Rod Out/Water Replaces } \\
\text { NaK/Water Around Axial and Radial Reflector }\end{array}$ & $0.999050 \pm 0.0021$ \\
$\begin{array}{l}\text { Drums In/Safety Rod In/Water Replaces } \\
\text { Nak/Water Around Axial and Radial Reflector }\end{array}$ & $0.967408 \pm 0.0010$ \\
$\begin{array}{l}\text { Safety Rod In/No Radial Reflector/Water } \\
\text { Replaces NaK/Water Around Vessel and Axial } \\
\text { Reflector }\end{array}$ & $0.984416 \pm 0.0019$ \\
\hline
\end{tabular}

Table XXVI. 40 kWe Yttrium Hydride Core - Neutron Kinetics Parameters ${ }^{1}$

\begin{tabular}{ccc}
$\begin{array}{c}\text { Delayed Neutron } \\
\text { Group } i\end{array}$ & Beta & $\begin{array}{c}\text { Lambda } \\
1 / \mathrm{Sec}\end{array}$ \\
\hline 1 & $2.6448 \mathrm{E}-4$ & $1.2720 \mathrm{E}-2$ \\
2 & $1.4745 \mathrm{E}-3$ & $3.1740 \mathrm{E}-2$ \\
3 & $1.3030 \mathrm{E}-3$ & $1.1600 \mathrm{E}-1$ \\
4 & $2.8182 \mathrm{E}-3$ & $3.1100 \mathrm{E}-1$ \\
5 & $8.8632 \mathrm{E}-4$ & $1.4000 \mathrm{E}+0$ \\
6 & $1.8003 \mathrm{E}-4$ & $3.8700 \mathrm{E}+00$ \\
\hline TOTAL & $6.9265 \mathrm{E}-3$ & \\
\hline
\end{tabular}

- Neutron Generation Time:

$1.267 \mathrm{E}-05 \mathrm{sec}$

Prompt Lifetime:

$1.289 \mathrm{E}-05 \mathrm{sec}$

- Effective Delayed Neutron Lifetime:

$1.274 \mathrm{E}+01 \mathrm{sec}$

${ }^{1}$ The effect of photoneutrons from $B e$ is not included in these results. 
Table XXVII. 40 kWe Yttrium Hydride Core - Hydrogen Loss

\begin{tabular}{lc}
\hline Base Case & $k=1.014147 \pm 0.0007$ \\
5 w\% Loss & $k=1.005871 \pm 0.0014$ \\
& $\Delta k(5 \%)=-0.008276 \pm 0.0016$ \\
10 w\% Loss & $\Delta=0.997507 \pm 0.0012$ \\
& $\Delta(10 \%)=-01664 \pm 0.0014$ \\
\hline *Basically: & $-1.66 \mathrm{E}-03\left(\Delta \mathrm{k} / \% \mathrm{H}_{2}\right.$ loss $)$ \\
\hline
\end{tabular}

Table XXVIII. 40 kWe Yttrium Hydride Core Modification 1 - Control Drums/Safety Rod Worth

\begin{tabular}{lll}
\hline Drums Out/Safety Rod Out & $1.056448 \pm 0.0021$ & \\
Drums In/Safety Rods Out & $0.992458 \pm 0.0020$ & \\
$\begin{array}{l}\text { Drums Worth ( } \Delta \mathrm{k} \%) \\
\text { Drums } \begin{array}{l}\text { In/Safety Rod In } \\
\text { Drums Plus Safety Rod Worth (\%) }\end{array}\end{array}$ & $0.957652 \pm 0.0022$ & 6.40 \\
\hline
\end{tabular}

* Not enough control worth in drums

Table XXIX. 40 kWe Yttrium Hydride Core Modification 1 - Submersion Analysis

- Water Replaces NaK in Core and Axial Reflector

- Water Surrounds Reactor

- Base Case: $k=1.056448 \pm 0.0021$

\begin{tabular}{lc}
\hline \multicolumn{1}{c}{ Configuration } & k-Effective \\
\hline Normal Configuration/No Water & $1.056448 \pm 0.0021$ \\
Drums In/Safety Rod In/Water Replaces NaK/Water & \\
Around Axial and Radial Reflector & $1.024317 \pm 0.0019$ \\
\hline *Problems for submersion & \\
\hline
\end{tabular}


Table XXX. 40 kWe Yttrium Hydride Core - Modification 2

A. No Gadolinia

A.1 Drums Out/Safety Rod Follower In $k=1.079526 \pm 0.0006$

A.2 Drums In/Safety Rod Follower In $k=1.009061 \pm 0.0017$

Drums Worth $=0.070465 \pm 0.0018$

A.3 Same as A.1 with Fuel Redistribution Axially (shape provided by SPI)

$$
k=1.075501 \pm 0.0025
$$

A.4 Same as A.1 with Fuel Redistribution Radially (no central void in fuel region)

$k=1.083954 \pm 0.0021$

A.5 Submersion/Safety Rod In/No Drums or Radial Reflector $k=1.036091 \pm 0.0023$

A.7 Same as A.1 but core dimensions and densities for hot isothermal $\mathrm{k}=1.079422 \pm 0.0009$ $\Delta k=-0.000104 \pm 0.0011$

A.8 Same as A.1 but NaK density at Hot Isothermal

$k=1.078837 \pm 0.0010$

$\Delta k=-0.000689 \pm 0.0012$ 
Table XXXI. 40 kWe Yttrium Hydride Core - Modification 2

B. With Gadolinia

B.1 Drums Out/Safety Rod Follower In

$k=1.043814 \pm 0.0020$

B.2 Drums In/Safety Rod Follower In

$k=0.962836 \pm 0.0012$

Drums Worth $=0.080978 \pm 0.0023$

B.3 Submersion/Safety Rod In/No Drums or Radial Reflector $k=0.996532 \pm 0.0017$

₹ Problem with submersion

Table XXXII. 10 kWe Yttrium Hydride Core - Core Characteristics

\begin{tabular}{ll}
\hline $\begin{array}{l}\text { Number of TFEs } \\
\text { Number of Drivers }\end{array}$ & 48 \\
Pitch (cm) & 6 \\
Equivalent Core Diameter (cm) & 36.4 \\
Core Active Length (cm) & 35.0 \\
U235 Fuel Loading (kg) & \\
TFEs & 27.1 \\
Drivers & 10.2 \\
U235 Enrichment (\%) & 90 \\
Fuel Smear Density (\%) & \\
TFEs & 73 \\
Drivers & 85 \\
Moderator & YH \\
Radial Reflector & \\
Material & Be \\
Thickness (cm) & 10 \\
Axial Reflector & \\
Material & Heterogeneous \\
Thickness (cm) & (detailed) \\
Control Drums & 10 \\
Number \\
Diameter (cm) \\
Material
\end{tabular}


Table XXXIII. $10 \mathrm{kWe}$ Yttrium Hydride Core TFE Cross Section

\begin{tabular}{lccc}
\hline \multicolumn{1}{c}{ Region } & OR $(\mathrm{cm})$ & Material & Density $(\mathrm{g} / \mathrm{cm})$ \\
\hline Void & 0.467 & -- & - \\
Fuel & 0.90 & $\mathrm{UO}_{2}(90 \%$ enr $)$ & 10.95 \\
Emitter & 1.0375 & Mo & 10.2 \\
Emitter & 1.05 & W $(2$ pass) & 19.1 \\
Gap & 1.08 & - & - \\
Collector & 1.18 & Mo & 10.2 \\
Gap & 1.22 & - & - \\
Sheath & 1.30 & SS316L & 7.9 \\
Coolant & 1.375 & NaK & 0.865 \\
Clad for Be & 1.40 & SS316L & 7.9 \\
Be Moderator & 1.94 & Be & 1.85 \\
W-182/W-183/W-184/W-186 $=1 / 18 / 80 / 1$ (Weight \%)
\end{tabular}

Table XXXIV. 10 kWe Yttrium Hydride Core Driver Cross Section

\begin{tabular}{lccc}
\hline \multicolumn{1}{c}{ Region } & OR $(\mathrm{cm})$ & Material & Density $(\mathrm{g} / \mathrm{cm})$ \\
\hline Void & 0.562 & - & - \\
Fuel & 1.45 & $\mathrm{UO}_{2}(90 \%$ enr $)$ & 10.95 \\
Clad & 1.525 & $\mathrm{SS} 316 \mathrm{~L}$ & 7.9 \\
Coolant & 1.600 & $\mathrm{NaK}$ & 0.865 \\
Clad & 1.625 & $\mathrm{SS} 316 \mathrm{~L}$ & 7.9 \\
Be & 1.94 & $\mathrm{Be}$ & 1.85 \\
\hline
\end{tabular}

Table XXXV. 10 kWe Yttrium Hydride Core Control Drums/Safety Rod Worths

\begin{tabular}{lll}
\hline Drums Out/Safety Rod Out & $1.039175 \pm 0.0021$ & \\
Drums In/Safety Rod Out & $0.965775 \pm 0.0020$ & \\
$\begin{array}{l}\text { Drums Worth }(\Delta \mathrm{k} \%) \\
\text { Drums In/Safety Rod In } \\
\text { Drums Plus Safety Rod Worth } \\
(\Delta \mathrm{k} \%)\end{array}$ & $0.903630 \pm 0.0015$ & 7.34 \\
\hline
\end{tabular}


Table XXXVI. 10 kWe Yttrium Hydride Core -

Temperature Reactivity Coefficients $\left[(\Delta \mathrm{k} / \mathrm{k}) /{ }^{\circ} \mathrm{K}\right]$

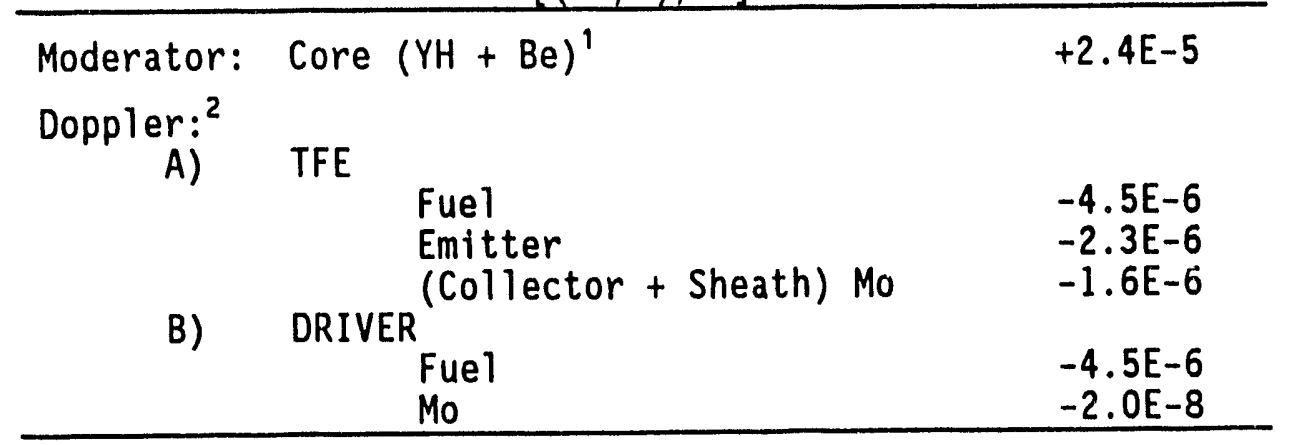

Table XXXVII. $10 \mathrm{kWe}$ Yttrium Hydride Core Submersion Analys is

- Water Replaces NaK in Core and Axial Reflector

- Water Surrounds Reactor

- Base Case: $k=1.039175 \pm 0.0021$

\begin{tabular}{lc}
\hline \multicolumn{1}{c}{ CONFIGURATION } & K-EFFECTIVE \\
\hline $\begin{array}{l}\text { Normal Configuration/No Water } \\
\text { Drums In/Safety Rod In/Water Replaces }\end{array}$ & $1.039175 \pm 0.0021$ \\
NaK/Water Around Axial and Radial Reflector & $0.941820 \pm 0.0020$ \\
$\begin{array}{l}\text { Safety Rod In/No Radial Reflector/Water } \\
\text { Replaces NaK/Water Around Vessel and Axial } \\
\text { Reflector }\end{array}$ & $0.951466 \pm 0.0025$ \\
\hline
\end{tabular}

${ }^{1}$ MCNP Analysis/Reactor Core Model/Temperature Range: 300 to $800 \mathrm{~K} /$ Mean Value Reported

${ }^{2} 1-D$ Transport (P3S8) Unit Ce11/97-Group XS generated for the $40 \mathrm{kWe} \mathrm{ZrH}$ Moderated Core/Temperature Range: 300 to $1000 \mathrm{~K}$ 


\section{DISTRIBUTION FOR ANL-EP-TM-92/1}

\section{Internal}

ANL Contract Copy

ANL Libraries (2)

ANL Patent Department

ANL Technical Publications Services (3)

S.K. Bhattacharyya
N.A. Hanan (10)

K.K. Larsen

L.G. LeSage

A.P. 01 son

R.R. Rudolph

\section{External}

DOE-OSTI (2)

Manager, Chicago Operations office, DOE

A.L. Taboas, DOE-CH-AAO

E.J. Britt - Space Power, Inc.

J. Dodson - Space Power, Inc.

N. Gunther - Space Power, Inc.

H. Rhee - Space Power, Inc.

J.R. Wetch - Space Power, Inc. 

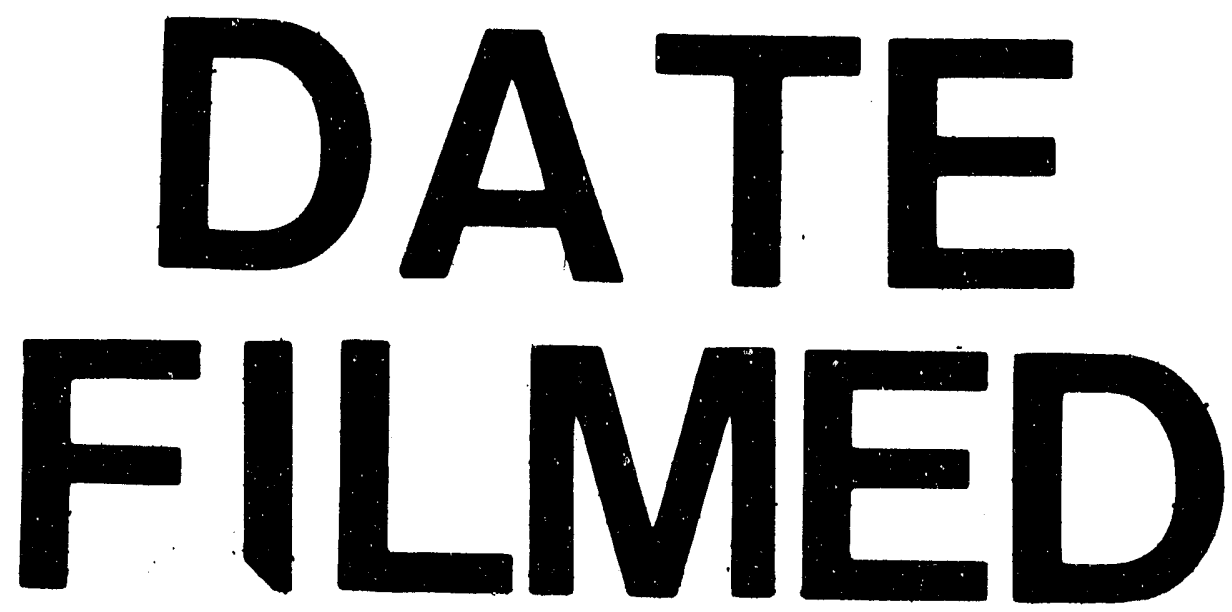

$01 / 21 / 93$ 
